\title{
The Expression of Genes Encoding Lipodepsipeptide Phytotoxins by Pseudomonas syringae pv. syringae Is Coordinated in Response to Plant Signal Molecules
}

\author{
Nian Wang, ${ }^{1}$ Shi-En Lu, ${ }^{1}$ Jianlin Wang, ${ }^{2}$ Z. Jeffrey Chen, ${ }^{2}$ and Dennis C. Gross ${ }^{1}$ \\ ${ }^{1}$ Department of Plant Pathology and Microbiology and ${ }^{2}$ Department of Soil and Crop Sciences, Texas A\&M University, \\ College Station 77843, U.S.A.
}

Submitted 16 August 2005. Accepted 25 October 2005.

\begin{abstract}
Specific plant signal molecules are known to induce syringomycin production and expression of $\operatorname{syr} B 1$, a syringomycin synthetase gene, in Pseudomonas syringae pv. syringae. This report demonstrates that syringopeptin production likewise is activated by plant signal molecules and that the GacS, SalA, and SyrF regulatory pathway mediates transmission of plant signal molecules to the syr-syp biosynthesis apparatus. Syringopeptin production by BR132 was increased twofold by addition of arbutin $(100 \mu \mathrm{M})$ and D-fructose $(0.1 \%)$ to syringomycin minimal medium (SRM). Among 10 plant phenolic compounds tested, only the phenolic glucosides arbutin, salicin, and phenyl- $\beta$-D-glucopyranoside induced substantially the $\beta$-glucuronidase (GUS) activity of a sypA::uidA reporter from $242 \mathrm{U}$ per $10^{8} \mathrm{CFU}$ without plant signal molecules up to $419 \mathrm{U}$ per $10^{8} \mathrm{CFU}$ with plant signal molecules. Syringopeptin production was found to be controlled by the SalA/SyrF regulon because no toxin was detected from cultures of B301DSL7 (i.e., salA mutant) and B301DSL1 (i.e., syrF mutant), and the expression of $\operatorname{syp} A$ ::uidA was decreased approximately 99 and $94 \%$ in salA (B301DSL30) and $\operatorname{syr} F$ (B301DNW31) mutant backgrounds, respectively. Subgenomic analysis of transcriptional expression with a 70mer oligonucleotide microarray demonstrated that the syrsyp genes are induced 2.5 - to 10.5 -fold by addition of arbutin and D-fructose to SRM. This study establishes that plant signal molecules are transmitted through the GacS, SalA/SyrF pathway to activate the coordinated transcriptional expression of the syr-syp genes.
\end{abstract}

Additional keywords: GacA, genomic island, Hrp, stimulon.

Bacteria commonly detect specific plant metabolites, which serve as signals for regulating expression of virulence genes that allow adaptation to the plant environment. For example, several virulence (vir) genes in Agrobacterium tumefaciens are

Corresponding author: D. C. Gross; Telephone: 1-979-845-8288; Fax: 1979-845-6483; E-mail: d-gross@tamu.edu

Current address of Nian Wang: Plant and Microbial Biology Department, University of California, Berkeley 94720, U.S.A.

Current address of S.-E. Lu: Department of Entomology and Plant Pathology, Mississippi State University, Mississippi State 39762, U.S.A.

* The $e$-Xtra logo stands for "electronic extra" and indicates that Figures 1 and 5 appear in color online. transcriptionally activated by specific phenolic signal molecules such as acetosyringone (Melchers et al. 1989). The induction is enhanced by pyranose sugars such as D-fructose, Dmannose, and D-glucose at low concentrations. Accordingly, the inducing sugars enhanced the expression of a virB::lacZ fusion more than 10 -fold at a $10 \mathrm{mM}$ concentration in the presence of $2.5 \mu \mathrm{M}$ acetosyringone (Ankenbauer and Nester 1990; Shimoda et al. 1990). Similarly, plant signal molecules were reported to activate the expression of genes involved in toxin synthesis (i.e., syringomycin and coronatine), cell wall degradation (i.e., pel), and the Hrp type III secretion system (Beaulieu et al. 1993; Li et al. 1998; Mo and Gross 1991; Quigley and Gross 1994; Xiao et al. 1992). Thus, plant signal molecules appear to play an important role in the interaction between plants and bacteria.

Syringomycin production is modulated by the perception of specific plant signal molecules (Mo et al. 1995; Mo and Gross 1991; Quigley and Gross 1994). Syringomycin is one of the major virulence factors of Pseudomonas syringae pv. syringae, which incites stem and leaf diseases in numerous monocot and dicot plants throughout the temperate regions of the world (Scholz-Schroeder et al. 2001a). Inoculations of immature cherry fruit demonstrated a rapid and strong expression of syrB1, a synthetase gene for syringomycin. Cherry tissues contain plant signal molecules, such as flavonol glycosides (quercetin and kaempferol 3-rutinosyl-4'-glucoside) and a flavanone glucoside (dihydrowogonin 7-glucoside), that are able to transcriptionally activate expression of a $\operatorname{syr} B 1:: \operatorname{lac} Z$ fusion (Mo et al. 1995). In a survey of 34 phenolic compounds, only specific phenolic glycosides exhibited syrBl-inducing activity. The phenolic glycosides that exhibited $s y r B 1$-inducing activity included arbutin, salicin, and esculin, which are abundant in the tissues of many plant species (Mo and Gross 1991). Arbutin was shown to be an efficient signal molecule that induced the high expression of the syrBl synthetase gene (Mo and Gross 1991). The plant signal molecules that activate toxin production by $P$. syringae pv. syringae are different from those that induce the vir genes of A. tumefaciens and the nod genes of rhizobia (Melchers et al. 1989; Mercier and Lindow 2000; Peters and Verma 1990). All syrB1-inducing phenolic signal molecules characteristically contain an intact glycosidic linkage. Specific sugars that occur in large quantities in leaf tissues markedly enhance phenolic signal activity (Mo et al. 1995; Mo and Gross 1991). D-fructose is the most active sugar, causing a 10-fold stimulation of signal activity in strain B3AR132 when phenolic signals are present at low concentrations (i.e., 1 to 10 
$\mu \mathrm{M})$. D-fructose and sucrose also exhibit intrinsic low-level syrB1-inducing signal activity in the absence of the phenolic inducer. Certain strains of the bacterium, such as B3A, require plant signal molecules for syringomycin production when grown under defined cultural conditions. Nearly all $P$. syringae pv. syringae strains produce higher syringomycin levels when the plant signal molecules arbutin and D-fructose are added to the media, but the extent of induction varies for individual strains. Several strains produce more than 10-fold higher toxin levels in the presence of arbutin and D-fructose, whereas other strains, including B301D, show approximately a twofold increase of syringomycin production (Quigley and Gross 1994).

Syringopeptin is another lipodepsipeptide that contributes to virulence of $P$. syringae pv. syringae (Scholz-Schroeder et al. 2001a). Syringopeptin and syringomycin have similar structures consisting of cyclic peptide heads attached to 3-hydroxy fatty acid tails. Both syringomycin and syringopeptin are synthesized by a nonribosomal mechanism of peptide biosynthesis (Grgurina et al. 1996; Scholz-Schroeder et al. 2001b). The syringomycin (syr) and syringopeptin (syp) gene clusters (Fig. 1) are located adjacent to one another on the chromosome and are approximately 42 and $90 \mathrm{~kb}$ in size, respectively (ScholzSchroeder et al. 2003). The syr and syp gene clusters include biosynthesis, regulatory, and secretion genes for syringomycin and syringopeptin production (Kang and Gross 2005; Lu et al. 2002; Quigley et al. 1993; Scholz-Schroeder et al. 2001b, 2003). Both syringomycin and syringopeptin production are controlled by the salA gene. Based on microarray analysis, the syr-syp genes belong to the SalA regulon ( $\mathrm{Lu}$ et al. 2005). $\mathrm{Mi}-$ croarray analysis is applicable to studies of the transcriptional regulation of the syr-syp genes simultaneously under defined environmental conditions ( $\mathrm{Lu}$ et al. 2005).

$P$. syringae utilizes a well-tuned regulatory and signal transduction system to coordinate the expression of virulence factors in order to adapt to the plant environment. The GacS/A twocomponent signal transduction system is well suited to sense and recognize environmental signals and to transduce these signals to downstream regulators (Heeb and Haas 2001). GacS is a transmembrane protein which functions as a histidine protein kinase that undergoes phosphorylation in response to environmental stimuli (Hrabak and Willis 1993). GacA is a response regulator protein that is phosphorylated by GacS (Heeb and Haas 2001; Rich et al. 1994). The GacS/A system is highly conserved in bacteria (Heeb and Haas 2001) and is dedicated to a variety of functions, such as pathogenicity (Hrabak and Willis 1993), quorum sensing (Chancey et al. 1999), secondary metabolite production (Corbell and Loper 1995), and biofilm formation (Parkins et al. 2001). It was reported that production of the lipopeptide amphisin by Pseudomonas sp. strain DSS73 is regulated by components of sugar beet seed exudates via the GacS/A two-component system (Koch et al. 2002). Mutational inactivation of either GacS or GacA in P. fluorescens CHA0 abolishes the response of exoproduct genes such as hcnA (for $\mathrm{HCN}$ synthetase) to an undefined solvent-extractable signal (Heeb et al. 2002). In P. syringae, the GacS/A two-component signal transduction system positively regulates expression of the salA gene (Kitten et al. 1998) which, in turn, is required for expression of $s y r F$ ( $\mathrm{Lu}$ et al. 2002). The regulatory gene $s y r F$ positively controls the expression of the syringomycin syrB1 synthetase gene (Lu et al. 2002). Previous studies showed that salA also is required for syringopeptin production, based on toxin bioassays, microarray analysis, and $\beta$-glucuronidase (GUS) assays (Lu et al. 2005). Chatterjee and associates (2003) showed that GacA is a master regulator controlling $P$. syringae pv. tomato DC3000 hrpR, hrpS, and hrpL, which are required for the activation of Hrp type III secretion and effector genes. GacA apparently is not required for hrp expression in P. syringae pv. syringae B728a (Chatterjee et al. 2003). Based on the high similarity between $P$. syringae pv. syringae $\mathrm{B} 728 \mathrm{a}$ and $\mathrm{B} 301 \mathrm{D}$, it was predicted that GacS/A is involved in the signal transduction of the B301D syr-syp genes, but not the hrp genes. Nevertheless, it is unknown whether plant signal molecules activate hrp genes in $P$. syringae pv. syringae, presumably through a regulatory network other than the $\mathrm{GacA} / \mathrm{GacS}$ regulon.

Despite progress made toward understanding the regulation of the $s y r$ and $h r p$ genes, little is known about the regulation of syringopeptin or the signal transduction pathway of the syr-syp and hrp genes in $P$. syringae pv. syringae B301D. In this study, it was hypothesized that specific plant signal molecules induce the coordinated expression of the syr-syp and hrp genes of $P$. syringae pv. syringae and that these two categories of genes use different signal transduction pathways. To test this hypothesis, a subgenomic 70-mer oligonucleotide microarray was used to measure the transcriptional profile of B301D grown on syringomycin minimal medium (SRM) agar medium as compared with SRM agar medium supplemented with arbutin and D-fructose (i.e., $\mathrm{SRM}_{\mathrm{AF}}$ ). Evidence is presented that the addition of arbutin and D-fructose resulted in significant in-

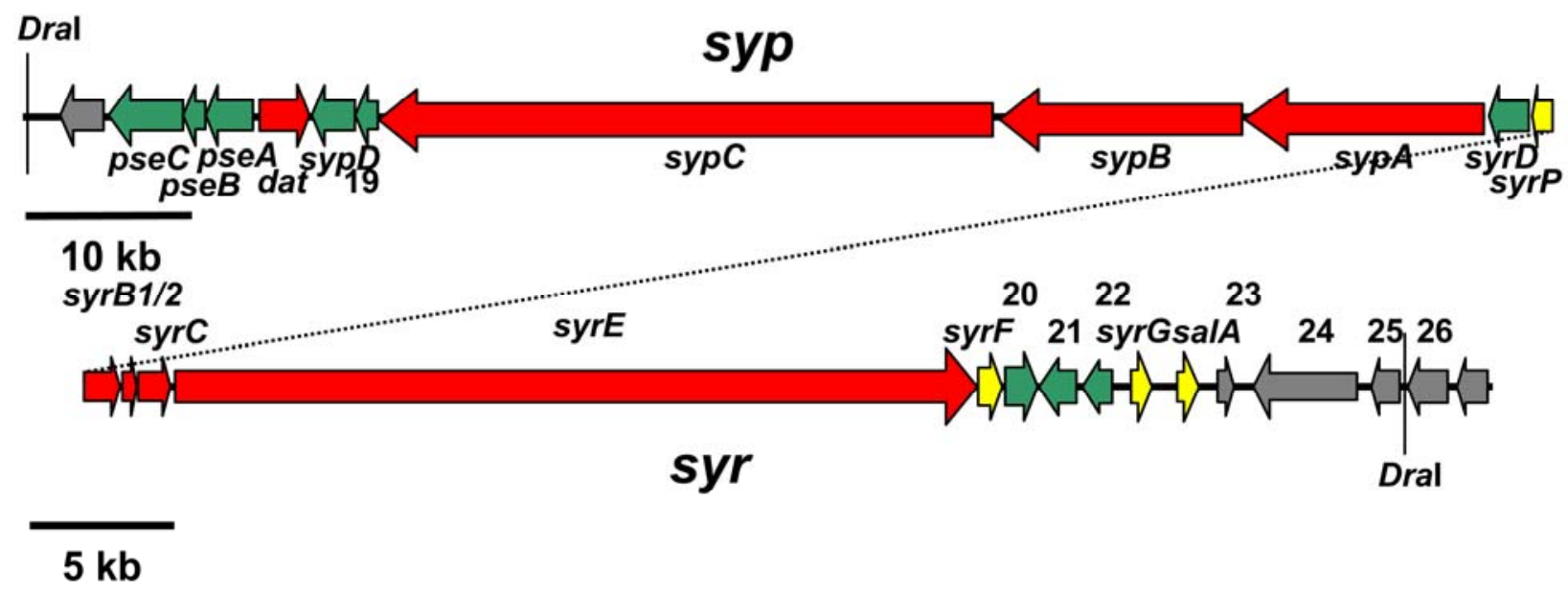

Fig. 1. Physical map of a 132-kb genomic DNA region of Pseudomonas syringae pv. syringae B301D containing both syringomycin (syr) and syringopeptin (syp) gene clusters. The positions and orientations of the known and potential open reading frames (ORFs) are shown as horizontal arrows. The solid, diagonally striped, and vertically striped arrows represent genes that are predicted to be involved in the synthesis, regulation, and secretion of the phytotoxins, respectively. The gray arrows represent the potential ORFs for which functions remain unknown. 
creases in transcriptional levels of the genes contributing to synthesis, secretion, and regulation of both syringomycin and syringopeptin, as well as the hrp genes. Mutational analysis of gacS showed that the GacS/A two-component system is involved in the signal transduction of the syr-syp genomic island but not representative genes associated with the Hrp type III secretion system. These results are discussed in regard to the involvement of the GacS/A two-component system and two key regulators, SalA and SyrF, in mediating plant signal transduction responsible for the transcriptional activity of genes associated with lipodepsipeptide phytotoxin production.

\section{RESULTS}

\section{Induction of syringopeptin production by plant signal molecules.}

Syringopeptin production was increased substantially for derivatives of strains B301DR and B3AR (i.e., syrB1 mutants BR132 and B3AR132) in the presence of arbutin $(100 \mu \mathrm{M})$ and fructose $(0.1 \%)$ as plant signal molecules. B3AR132 did not produce a visible zone of syringopeptin inhibitory to Bacillus megaterium growth on SRM agar medium, but the radius of the inhibitory zone was approximately $4.7 \mathrm{~mm}$ on $\mathrm{SRM}_{\mathrm{AF}}$ agar medium (Fig. 2). Addition of arbutin and fructose increased the radius of the inhibitory zone produced by BR 132 by $4 \mathrm{~mm}$, representing a $66.7 \%$ increase in size. Syringomycin was not detected for B3A in the absence of plant signal molecules in a bioassay using Geotrichum candidum, but a small zone of inhibition was observed on $\mathrm{SRM}_{\mathrm{AF}}$ agar medium. The sizes of the zones of syringomycin production by B301D were $55.6 \%$

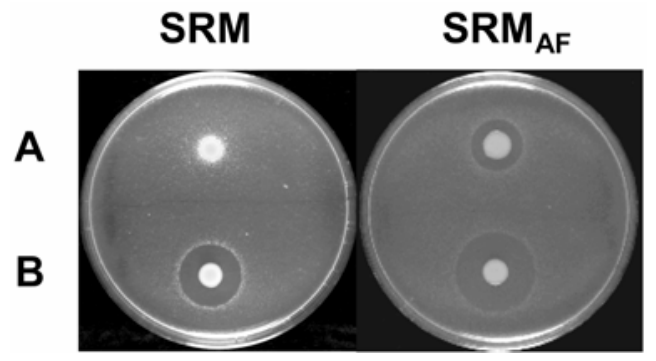

Fig. 2. Bioassay for syringopeptin production by two strains of Pseudomonas syringae pv. syringae grown on syringomycin minimal medium without (SRM) or with $100 \mu \mathrm{M}$ arbutin and $0.1 \%$ D-fructose $\left(\mathrm{SRM}_{\mathrm{AF}}\right)$ as shown by zones inhibitory to Bacillus megaterium. The strains were grown for 4 days on plates at $25^{\circ} \mathrm{C}$. Plates were oversprayed with $B$. megaterium and allowed to incubate for $24 \mathrm{~h}$ at $25^{\circ} \mathrm{C}$. Zones of inhibition indicate production of syringopeptin. A, B3AR132 (syrB1 mutant) and B, BR132 (syrB1 mutant). larger on $\mathrm{SRM}_{\mathrm{AF}}$ agar medium than on SRM agar medium. Consistent results were obtained with repeats on three independent occasions.

\section{Induction of sypA.}

The expression of syrB1::uidA fusion strain B301DSL8 was increased 1.66-, 1.53-, and 1.55-fold by addition of $100 \mu \mathrm{M}$ of the phenolic $\beta$-glucosides arbutin, phenyl- $\beta$-D-glucopyranoside, and salicin to SRM liquid medium, respectively (Table 1). Similarly, the expression of a sypA::uidA fusion strain (B301DSL29) was increased 1.52- to 1.73-fold on SRM with the phenolic glucosides (Table 1). Arbutin was the most active inducer for both genes (Table 1). Other phenolic compounds (hydroquinone, naringenin, phenol, phenyl- $\beta$-D-galactopyranoside, quercetin, rutin, and saligenin) tested did not show significant effect on expression of either syrB1::uidA or sypA::uidA fusions.

A $\beta$-glucosidic linkage was shown to be critical to signal activity. This was evaluated by testing the substituted derivatives of arbutin, phenyl- $\beta$-D-glucopyranoside and salicin (i.e., hydroquinone, saligenin, and phenol) (Table 1). All three phenolic aglucones were inactive in induction of both $\operatorname{syrB1}:$ :uidA and sypA::uidA fusions.

Once it was confirmed that certain phenolic $\beta$-glycosides induced the expression of sypA, the effects of the sugar D-fructose on arbutin-mediated induction of $s y p A$ and $s y r B 1$ were determined. Strain B301DSL8, which carries the syrB1::uidA fusion, produced high levels of GUS activity, averaging 1,274 units per $10^{8} \mathrm{CFU} 3$ days after incubation at $25^{\circ} \mathrm{C}$ in $\mathrm{SRM}_{\mathrm{AF}}$

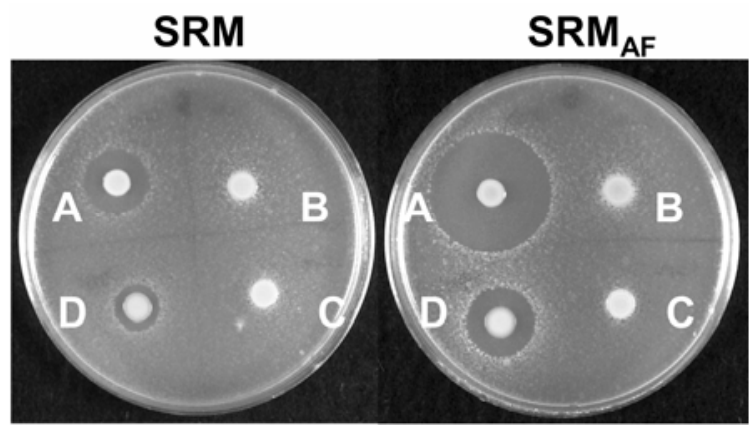

Fig. 3. Bioassay for syringopeptin production by different strains of $\mathrm{Pseu}$ domonas syringae pv. syringae B301D grown on syringomycin minimal medium without (SRM) or with $100 \mu \mathrm{M}$ arbutin and $0.1 \%$ D-fructose $\left(\mathrm{SRM}_{\mathrm{AF}}\right)$ as shown by zones inhibitory to Bacillus megaterium. The strains were grown on plates at $25^{\circ} \mathrm{C}$ for 4 days. Plates were oversprayed with $B$. megaterium and allowed to incubate for $24 \mathrm{~h}$ at $25^{\circ} \mathrm{C}$. Zones of inhibition indicate production of syringopeptin. A, BR132 (syrB1 mutant); B, B301DSL7 (salA mutant); C, B301DSL1 (syrF mutant); and D, B301D.

Table 1. Effects of plant phenolic $\beta$-glycosides on induction of sypA::uidA and syrB1::uidA fusions in strains B301DSL29 and B301DSL8, respectively

\begin{tabular}{|c|c|c|c|c|}
\hline \multirow[b]{2}{*}{ Phenolics added to SRM ${ }^{y}$} & \multicolumn{2}{|c|}{ sypA::uidA } & \multicolumn{2}{|c|}{ syrB1::uidA } \\
\hline & GUS activity $\left(\mathrm{U} / 10^{8} \mathrm{CFU} \pm \mathrm{SE}\right)^{\mathrm{z}}$ & Fold increase & GUS activity $\left(\mathrm{U} / 10^{8} \mathrm{CFU} \pm \mathrm{SE}\right)^{\mathrm{z}}$ & Fold increase \\
\hline None & $242 \pm 14 \mathrm{a}$ & $\ldots$ & $685 \pm 63 a$ & $\ldots$ \\
\hline Arbutin & $419 \pm 30 b$ & 1.73 & $1,140 \pm 73 b$ & 1.66 \\
\hline Phenyl- $\beta$-D-glucopyranoside & $389 \pm 24 b$ & 1.60 & $1,050 \pm 44 b$ & 1.53 \\
\hline Salicin & $369 \pm 18 b$ & 1.52 & $1,060 \pm 32 b$ & 1.55 \\
\hline Hydroquinone & $298 \pm 19 a$ & 1.23 & $755 \pm 48 \mathrm{a}$ & 1.1 \\
\hline Saligenin & $279 \pm 27 \mathrm{a}$ & 1.15 & $732 \pm 33 a$ & 1.07 \\
\hline Naringenin & $273 \pm 23 a$ & 1.13 & $710 \pm 36 a$ & 1.04 \\
\hline Phenol & $269 \pm 22 a$ & 1.11 & $698 \pm 51 a$ & 1.02 \\
\hline Quercetin & $268 \pm 29 a$ & 1.10 & $667 \pm 23 a$ & 0.97 \\
\hline Phenyl- $\beta$-D-galactopyranoside & $252 \pm 33 a$ & 1.04 & $638 \pm 57 a$ & 0.93 \\
\hline Rutin & $241 \pm 22 a$ & 0.99 & $686 \pm 40 a$ & 1.00 \\
\hline
\end{tabular}

y All phenolic compounds tested at a final concentration of $100 \mu \mathrm{M}$ in syringomycin minimal medium (SRM).

${ }^{\mathrm{z}}$ GUS = $\beta$-glucuronidase. Activities are the mean of six independent assays followed by the standard error (SE) of mean. Different letters indicate statistically significant differences $(\alpha=0.01)$. Differences between treatments were determined by Tukey's analysis of variance. 
liquid medium. Without plant signal molecules, GUS activity of B301DSL8 averaged only 685 units per $10^{8}$ CFU. Similarly, the GUS activity of B301DSL29, which contains the sypA::uidA reporter, was increased from 242 to 528 units per $10^{8} \mathrm{CFU}$ in the presence of arbutin $(100 \mu \mathrm{M})$ and fructose $(0.1 \%)$. Consequently, the expression of $s y r B 1$ and $s y p A$ were increased 1.9- and 2.1-fold, respectively, by addition of arbutin and fructose to SRM liquid medium.

\section{The salA and $s y r F$ regulatory pathway mediates induction} of syringopeptin production and $\operatorname{syp} A$ expression.

Neither B301DSL7, a salA mutant, nor B301DSL1, a syrF mutant, produced detectable syringopeptin zones of inhibition to B. megaterium $\mathrm{Km}$ on $\mathrm{SRM}$ or $\mathrm{SRM}_{\mathrm{AF}}$ agar media (Fig. 3). B301DSL6, a syrG mutant, did not produce detectable zones of inhibition on SRM agar medium, but did produce syringopeptin on $\mathrm{SRM}_{\mathrm{AF}}$ agar medium (not shown). Expression of the sypA::uidA reporter was reduced approximately $99 \%$ in salA strain B301DSL30 (Lu et al. 2005) in both SRM and $\mathrm{SRM}_{\mathrm{AF}}$ liquid media. Expression of the sypA::uidA reporter was decreased by 93.7 and $96.4 \%$ in $s y r F$ strain B301DNW31 in SRM and $\mathrm{SRM}_{\mathrm{AF}}$ media, respectively. Neither the salA mutant B301DSL30 nor the syrF mutant B301DNW31 exhibited a significant increase in GUS activity upon the addition of plant signal molecules.

\section{Microarray analysis of the effects of plant signal molecules on expression of virulence-related genes.}

Analysis with a 70-mer oligonucleotide subgenomic microarray showed that 26 of 95 genes were induced significantly greater than twofold by addition of arbutin $(100 \mu \mathrm{M})$ and $\mathrm{D}$ fructose $(0.1 \%)$ (Table 2$)$. In this study, no gene or open reading frame (ORF) included was observed to have an expression ratio below 0.5 , which indicates that no gene or ORF included in the microarray was negatively regulated by plant signal molecules. Genes dedicated to biosynthesis, secretion, and regulation of syringomycin and syringopeptin were induced by plant signal molecules. The expression of all of the syringopeptin synthetase genes, including $\operatorname{syp} A$, sypB, and $s y p C$ (ScholzSchroeder et al. 2003) (Fig. 1; Table 2), was increased 5.4- to 7.8-fold by addition of arbutin and D-fructose to SRM. The expression of all of the syringomycin biosynthesis genes, includ-

Table 2. Microarray analysis of the stimulon controlled by plant signal molecules

\begin{tabular}{|c|c|c|c|}
\hline Genes $^{\mathbf{y}}$ & Ratio $(\text { SEM })^{\mathbf{z}}$ & Gene product & References \\
\hline syrD & $4.71( \pm 0.40)$ & ATP-binding secretion protein & Quigley et al. 1993 \\
\hline syrP & $7.76( \pm 0.61)$ & Homologue of histidine kinase & Zhang et al. 1997 \\
\hline syrB 1 & $5.23( \pm 0.40)$ & Syringomycin biosynthesis enzyme & Zhang et al. 1995 \\
\hline syrB2 & $5.41( \pm 0.80)$ & Syringomycin biosynthesis enzyme & Zhang et al. 1995 \\
\hline $\operatorname{syrC}$ & $10.51( \pm 0.66)$ & Syringomycin biosynthesis enzyme & Zhang et al. 1995 \\
\hline syrE-1 & $4.40( \pm 0.55)$ & Syringomycin synthetase & Guenzi et al. 1998 \\
\hline syrE-2 & $6.99( \pm 0.83)$ & Syringomycin synthetase & Guenzi et al. 1998 \\
\hline syrE-3 & $8.03( \pm 0.89)$ & Syringomycin synthetase & Guenzi et al. 1998 \\
\hline syrF & $3.89( \pm 0.81)$ & LuxR family bacterial regulator & Lu et al. 2002 \\
\hline ORF 20 & $6.18( \pm 0.93)$ & Putative out membrane protein & Lu et al. 2005 \\
\hline ORF21 & $2.53( \pm 0.48)$ & Hypothetical protein & Lu et al. 2005 \\
\hline ORF22 & $6.45( \pm 1.29)$ & Membrane protein & Lu et al. 2005 \\
\hline syrG & $3.08( \pm 0.69)$ & LuxR family regulatory protein & Lu et al. 2002 \\
\hline salA & $2.50( \pm 0.19)$ & LuxR family bacterial regulator & Lu et al. 2002 \\
\hline ORF 23 & $0.99( \pm 0.07)$ & Hypothetical protein & Lu et al. 2005 \\
\hline ORF $24-1$ & $0.85( \pm 0.13)$ & Hypothetical protein & Lu et al. 2005 \\
\hline$O R F 24-2$ & $0.92( \pm 0.03)$ & Hypothetical protein & Lu et al. 2005 \\
\hline ORF 25 & $0.94( \pm 0.20)$ & Hypothetical protein & Lu et al. 2005 \\
\hline ORF 26 & $1.02( \pm 0.14)$ & Unknown (chemotaxis protein) & Lu et al. 2005 \\
\hline sypA & $6.16( \pm 0.64)$ & Syringopeptin synthetase & Scholz-Schroeder et al. 2003 \\
\hline syp $B-1$ & $7.78( \pm 0.74)$ & Syringopeptin synthetase & Scholz-Schroeder et al. 2003 \\
\hline $\operatorname{syp} B-2$ & $5.41( \pm 0.80)$ & Syringopeptin synthetase & Scholz-Schroeder et al. 2003 \\
\hline syp $C 1$ & $5.79( \pm 1.09)$ & Syringopeptin synthetase & Scholz-Schroeder et al. 2003 \\
\hline syp $C 2$ & $5.75( \pm 1.32)$ & Syringopeptin synthetase & Scholz-Schroeder et al. 2003 \\
\hline ORF 19 & $3.49( \pm 0.16)$ & Putative membrane protein & H. Kang and D. C. Gross, unpublished \\
\hline sypD & $6.23( \pm 0.59)$ & Putative ABC transporter & H. Kang and D. C. Gross, unpublished \\
\hline dat & $6.23( \pm 0.65)$ & Aminotransferase & H. Kang and D. C. Gross, unpublished \\
\hline pseA & $4.33( \pm 0.74)$ & Putative outer membrane protein & Kang and Gross 2005 \\
\hline pseB & $1.56( \pm 0.15)$ & Efflux membrane fusion protein & Kang and Gross 2005 \\
\hline pseC & $1.64( \pm 0.14)$ & Efflux membrane fusion protein & Kang and Gross 2005 \\
\hline ORF 14 & $1.03( \pm 0.07)$ & Putative chemotaxis protein & N. Wang and D. C. Gross, unpublished \\
\hline ORF 13 & $0.91( \pm 0.08)$ & Unknown & N. Wang and D. C. Gross, unpublished \\
\hline ORF 12 & $1.02( \pm 0.09)$ & Sensor protein & N. Wang and D. C. Gross, unpublished \\
\hline ORF 11 & $0.79( \pm 0.09)$ & Amino acid deaminase & N. Wang and D. C. Gross, unpublished \\
\hline ORF 10 & $1.30( \pm 0.16)$ & Hypothetical protein & N. Wang and D. C. Gross, unpublished \\
\hline ORF9 & $1.20( \pm 0.11)$ & Hypothetical protein & N. Wang and D. C. Gross, unpublished \\
\hline ORF8 & $1.17( \pm 0.10)$ & Hypothetical protein & N. Wang and D. C. Gross, unpublished \\
\hline ORF7 & $1.06( \pm 0.14)$ & Hypothetical protein & N. Wang and D. C. Gross, unpublished \\
\hline ORF6 & $0.84( \pm 0.19)$ & Hypothetical protein & N. Wang and D. C. Gross, unpublished \\
\hline ORF5 & $0.88( \pm 0.08)$ & Hypothetical protein & N. Wang and D. C. Gross, unpublished \\
\hline ORF4 & $1.25( \pm 0.45)$ & Hypothetical protein & N. Wang and D. C. Gross, unpublished \\
\hline ORF3 & $0.75( \pm 0.08)$ & Hypothetical protein & N. Wang and D. C. Gross, unpublished \\
\hline$O R F 2$ & $1.27( \pm 0.17)$ & Hypothetical protein & N. Wang and D. C. Gross, unpublished \\
\hline & & & (continued on next page) \\
\hline
\end{tabular}

y The psyr numbers stand for open reading frames listed on the Department of Energy's Joint Genome Institute website.

${ }^{\mathrm{z}}$ The ratio was determined by comparing gene transcription (measured by signal intensity) in Pseudomonas syringae pv. syringae B301D cultured on syringomycin minimal medium (SRM) supplemented with arbutin and D-fructose $\left(\mathrm{SRM}_{\mathrm{AF}}\right)$ medium to that of B301D cultured on SRM. Data shown in the table are the means of the three independent experiments with the standard errors of means (SEM). 
ing syrB1, syrB2, syrC, and syrE genes (Guenzi et al. 1998; Lu et al. 2002) (Fig. 1; Table 2), was increased 4.4- to 10.5-fold by addition of plant signal molecules (Table 2). The expression levels observed from three 70-mer oligonucleotide arrays (sequences available from authors upon request) designed from different locations in $s y r E$ showed greater than fourfold increases with the addition of arbutin and D-fructose (Table 2). Three major regulatory genes located at the right border of the syr-syp genomic island, salA, syrF, and $s y r G$, were upregulated by 2.5-, 3.9-, and 3.1-fold, respectively. Expression of most secretion genes in the syr-syp genomic island, including syrD, sypD, two $m \operatorname{tr} C$ homologues, one oprM homologue, and pseA, was increased to higher levels of 2.5 to 6.5 times by plant signal molecules. In addition to the syr-syp genes, the hrp genes $h r p Z, h r p R, h r p L, h r p W, h r m A$, and $h r p K$ (Alfano et al. 2000; Collmer et al. 2000) included on the microarray were induced more than twofold in the presence of plant signal molecules (Table 2).

The availability of a transcriptional profile for B301D compared with B301DSL7 on potato dextrose agar, as reported by $\mathrm{Lu}$ and associates (2005), and that of B301D on SRM agar medium with or without exogenously added arbutin $(100 \mu \mathrm{M})$ and fructose $(0.1 \%)$, in this study, facilitated cluster analysis of oligonucleotide microarray data with the self-organizing tree algorithm (SOTA) (Herrero et al. 2001). All of the induced genes were grouped into two clusters based on SOTA analysis (Fig. 4), with the syr-syp genes clustered together and the hrp/avr genes forming a second cluster.

Housekeeping genes such as sigX (Brinkman et al. 1999), $\operatorname{alg} T$ (Keith and Bender 1999), algD (Fakhr et al. 1999), sodB (Hassett et al. 1993), and inaK (Li et al. 2004), located outside of the syr-syp genomic island, were expressed at high levels on both SRM and $\mathrm{SRM}_{\mathrm{AF}}$ media with no significant differences in expression levels between these two media. Genes involved in siderophore production (i.e., $p v d S$ [Mossialos et al. 2002], $p v d E$ [McMorran et al. 1996], $f s c$ [Nelson et al. 2002], $a c s D$ [Franza et al. 2005], $c b r B$ [Mahé et al. 1995], $c b r D$ [Mahé et al. 1995], and fur [Hassett et al. 1996]), environmental stress (rulA) (Zhang and Sundin 2004), quorum sensing (ahll) (Kinscherf and Willis 1999), global regulation (i.e., gacS, gacA, rpoN [Alarcón-Chaidez et al. 2003; Cui et al. 2001], rpoS [HenggeAronis 1993], and rpoD [Tanaka and Takahashi 1991]), phyto-

Table 2. Continued from preceding page

\begin{tabular}{|c|c|c|c|}
\hline Genes $^{y}$ & Ratio $(\mathrm{SEM})^{\mathrm{z}}$ & Gene product & References \\
\hline ORF1 & $1.03( \pm 0.10)$ & Hypothetical protein & N. Wang and D. C. Gross, unpublished \\
\hline hrpL & $2.93( \pm 0.44)$ & Alternative sigma factor & Alfano et al. 2000 \\
\hline$h r p R$ & $2.10( \pm 0.18)$ & Regulatory factor & Xiao and Hutcheson 1994 \\
\hline hrpS & $1.87( \pm 0.26)$ & Positive regulatory factor & Xiao and Hutcheson 1994 \\
\hline hrpK & $2.27( \pm 0.40)$ & Unknown & Wang and Gross, unpublished \\
\hline hrpJ & $1.01( \pm 0.16)$ & Flagella biogenesis & Lidell and Hutcheson 1994 \\
\hline hrpZ & $3.95( \pm 0.28)$ & Harpin & He et al. 1993 \\
\hline$h r p W$ & $2.63( \pm 0.23)$ & Type III effector & Charkowski et al. 1998 \\
\hline queA & $1.02( \pm 0.11)$ & Exchangeable effector locus & Alfano et al. 2000 \\
\hline EEl-chp & $2.0( \pm 0.28)$ & Type III chaperone protein & N. Wang and D. C. Gross, unpublished \\
\hline hrmA & $2.24( \pm 0.28)$ & Avr (effector) proteins & Alfano et al. 2000 \\
\hline $\operatorname{gacS}$ & $1.56( \pm 0.26)$ & Sensor protein & Willis et al. 1990 \\
\hline gacA & $1.57( \pm 0.35)$ & Regulator protein & Rich et al. 1994 \\
\hline rpos & $1.41( \pm 0.08)$ & RNA polymerase sigma factor & Hengge-Aronis 1993 \\
\hline rроD & $1.13( \pm 0.06)$ & Principle sigma factor & Tanaka and Takahashi 1991 \\
\hline rpoN & $0.82( \pm 0.06)$ & Putative sigma-54 protein & Alarcón-Chaidez et al. 2003 \\
\hline $\operatorname{sig} X$ & $1.37( \pm 0.23)$ & Sigma factor & Brinkman et al. 1999 \\
\hline psyr020094 & $1.28( \pm 0.22)$ & Putative NRPS & JGI Integrated Microbial Genomes website \\
\hline psyr020651 & $1.86( \pm 0.14)$ & Putative NRPS & JGI Integrated Microbial Genomes website \\
\hline sylD & $1.16( \pm 0.11)$ & Putative syringolin synthetase & Amrein et al. 2004 \\
\hline $\operatorname{alg} T$ & $1.16( \pm 0.05)$ & Alternative sigma factor & Keith and Bender 1999 \\
\hline $\operatorname{alg} D$ & $0.84( \pm 0.22)$ & GDP-mannose dehydrogenase & Fakhr et al. 1999 \\
\hline iaaM & $1.21( \pm 0.14)$ & Tryptophan monooxygenase & Mazzola and White 1994 \\
\hline$i a a H$ & $0.84( \pm 0.07)$ & Indoleacetamide hydrolase & Mazzola and White 1994 \\
\hline ahlI & $1.97( \pm 0.20)$ & Acyl homoserine lactone synthetase & Kinscherf and Willis 1999 \\
\hline $\operatorname{inaK}$ & $0.81( \pm 0.09)$ & Ice nucleation protein & Li et al. 2004 \\
\hline$p v d S$ & $0.86( \pm 0.09)$ & Putative acetylase & Mossialos et al. 2002 \\
\hline$p v d E$ & $0.83( \pm 0.06)$ & Pyoverdine synthetase & McMorran et al. 1996 \\
\hline fur & $1.19( \pm 0.14)$ & Ferric uptake regulator & Franza et al. 2005 \\
\hline $\operatorname{lcc} C$ & $2.09( \pm 0.66)$ & Levansucrase & Li and Ullrich 2001 \\
\hline$c b r B$ & $1.03( \pm 0.13)$ & Ferrisiderophore permease & Mahé et al. 1995 \\
\hline $\operatorname{cbrD}$ & $0.81( \pm 0.09)$ & ATP-binding unit in $\mathrm{ABC}$ transport & Mahé et al. 1995 \\
\hline $\operatorname{acs} D$ & $0.77( \pm 0.04)$ & Achromobactin biosynthetase & Franza et al. 2005 \\
\hline$f_{s c}$ & $0.81( \pm 0.07)$ & Ferric siderophore receptor & Nelson et al. 2002 \\
\hline$S R$-dat & $0.80( \pm 0.05)$ & Diaminobutyrate transaminase & Ikai and Yamamoto 1997 \\
\hline psyr020143 & $1.02( \pm 0.19)$ & Putative NRPS & Department of Energy's JGI website \\
\hline tex & $0.85( \pm 0.07)$ & S1 RNA binding domain protein & Nelson et al. 2002 \\
\hline$g \operatorname{sh} A$ & $1.27( \pm 0.09)$ & Glutamate-cysteine ligase & Nelson et al. 2002 \\
\hline $\arg A$ & $1.15( \pm 0.09)$ & $\mathrm{N}$-acetylglutamate synthetase & Lu et al. 2003 \\
\hline $\arg E$ & $0.92( \pm 0.11)$ & Acetylornithine deacetylase & Lu et al. 2003 \\
\hline SA-ORF6 & $0.90( \pm 0.12)$ & Unknown & Lu et al. 2003 \\
\hline rulA & $0.85( \pm 0.09)$ & Radiation tolerance & Sundin and Murillo 1999 \\
\hline $\operatorname{sod} B$ & $1.11( \pm 0.05)$ & Iron-superoxide dismutase & Hassett et al. 1993 \\
\hline $\operatorname{gyr} B$ & $0.79( \pm 0.04)$ & DNA gyrase subunit B & Sawada et al. 1999 \\
\hline recA & $1.51( \pm 0.21)$ & Principal sigma factor & Kokjohn and Miller 1985 \\
\hline luc & $0.86( \pm 0.10)$ & Luciferase & Coronado et al. 1994 \\
\hline negc10 & $0.98( \pm 0.33)$ & Random primer & Qiagen \\
\hline $16 \mathrm{~S}$ rDNA & $1( \pm 0.0)$ & $16 \mathrm{~S}$ ribosomal RNA & Nelson et al. 2002 \\
\hline
\end{tabular}




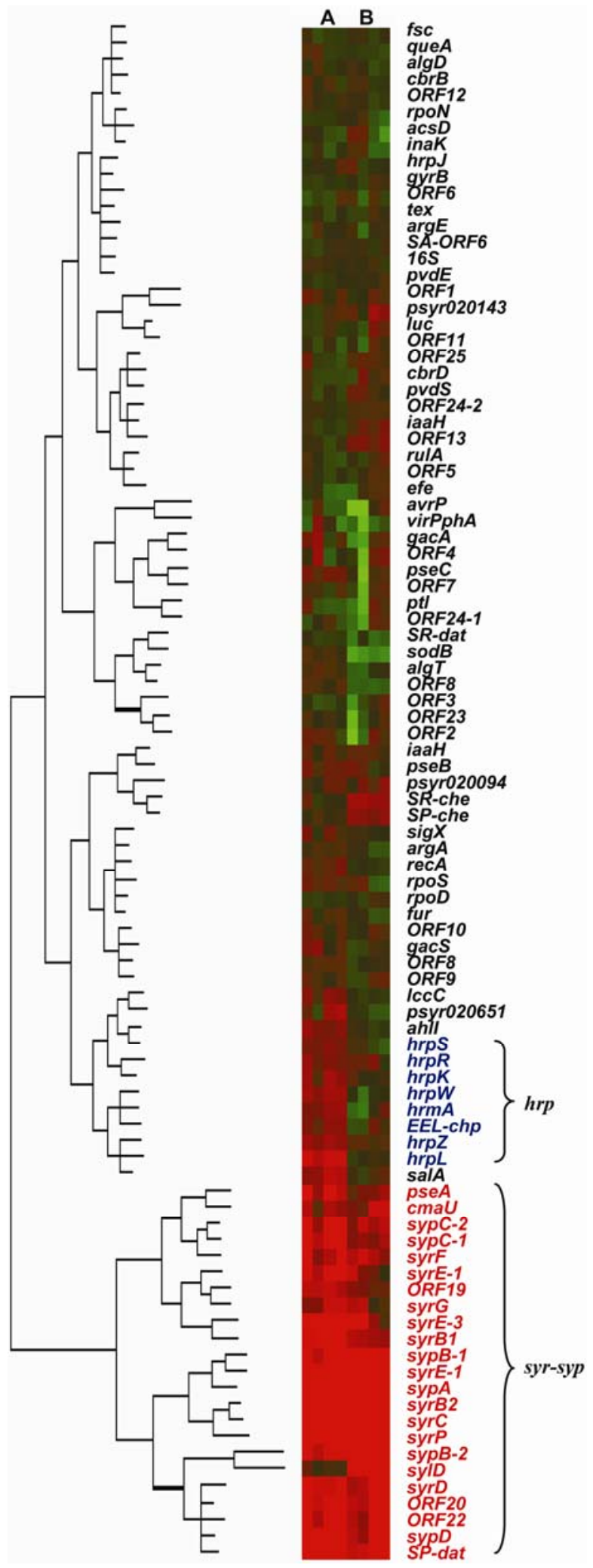

Fig. 4. Unsupervised hierarchical clustering analysis of syr-syp and representative genes. Column A represents comparisons between B301D on $\mathrm{SRM}$ and $\mathrm{SRM}_{\mathrm{AF}}$ agar media. Column B represents comparisons of gene expression between B301D and B301DSL7, a salA mutant. The scale of gene activities is represented from green (not induced or induced at low level) to red (induced at high level). The cluster analysis of microarray data was performed with the self-organizing tree algorithm. The syr-syp genes that clustered together are in red text. The genes associated with the Hrp type III secretion system that are clustered together are in blue text. hormone synthesis (iaaM and iaaH) (Mazzola and White 1994), and alginate production (algD) (Koopmann et al. 2001) were not affected by plant signal molecules.

\section{Independent microarray validation using GUS assays and quantitative real-time transcription polymerase chain reaction.}

In addition to the microarray results of plant signal molecules on syr-syp genes, 10 genes (9 induced genes [i.e., syrB1, syrC, sypA, sypB, hrpR, hrpZ, salA, syrF, and syrG] and 1 unaffected gene [i.e., recA]) that represent a range of changes observed in microarray studies (0.8- to 10.5 -fold changes) were validated by GUS assays and quantitative real-time transcription polymerase chain reaction (QRT-PCR) analysis. GUS assays corroborated the direction of regulation observed from microarray analysis for all three regulatory genes, including salA, syrF, and syrG, located at the right border of the syr gene cluster. Based on quantitative GUS assays, expression of pSL40F (salA::uidA), pSL38F (syrF::uidA), and pSL39F (syrG::uidA) was significantly increased by addition of arbutin and D-fructose. Strain B301D, carrying pSL40F, pSL38F, or pSL39F, demonstrated GUS activity of 1,059, 1,700, and 535 units per $10^{8} \mathrm{CFU}$, respectively, $72 \mathrm{~h}$ after incubation at $25^{\circ} \mathrm{C}$ in SRM liquid medium. In contrast, their expression levels reached 1,918, 2,711, and 1,220 units per $10^{8} \mathrm{CFU}$, respectively, in $\mathrm{SRM}_{\mathrm{AF}}$ liquid medium. Therefore, the expression levels of salA, syrF, and $s y r G$ were increased 1.81-, 1.59-, and 2.24-fold, respectively, by addition of plant signal molecules.

The regulation patterns defined by QRT-PCR were similar to those determined by the microarray data. Based on QRT-PCR analysis, the fold induction by arbutin and fructose on $s y r B 1$, syrC, sypA, sypB, hrpZ, hrpR, and recA were 8.4, 16.3, 4.3, $25.7,13.8,6.0$, and 1.2 , respectively (Table 3 ). In comparison, the induction levels by microarray analysis were increased by 5.2-, 10.5-, 6.2-, 6.6-, 2.1-, 4.0-, and 1.5-fold, respectively (Table 2). The greatest difference in changes was obtained for sypB; the change of transcriptional level determined by QRTPCR analysis was 25.7-fold, compared with a 6.6-fold change in expression by microarray analysis.

\section{Induction of syr-syp and type III genes}

via different regulatory pathways.

QRT-PCR was used to evaluate the effect of a $g a c S$ disruption on the induction of syr-syp and hrp genes. The gacS mutant (B301DG12) was inoculated on SRM and SRM $\mathrm{AF}_{\mathrm{AF}}$ media for 3 days at $25^{\circ} \mathrm{C}$ as described above. In a gacS mutant, the transcriptional expression increase of $\operatorname{syp} A, \operatorname{syp} B, \operatorname{syr} B 1$, and syr $C$ caused by plant signal molecules was reduced to 1.0-, 3.4-,

Table 3. Quantitative real-time polymerase chain reaction analysis of expression of representative genes of strains B301D and B301DG12 (gacS mutant) as influenced by the presence of plant signal molecules

\begin{tabular}{lcc}
\hline & \multicolumn{2}{c}{$\begin{array}{c}\text { Change in transcriptional level }( \pm \mathbf{S E}) \\
\text { on SRM versus } \mathbf{S R M}_{\mathbf{A F}}{ }^{\mathbf{z}}\end{array}$} \\
\cline { 2 - 3 } Gene & B301D & B301DG12 \\
\hline syrB1 & $8.4 \pm 0.7$ & $1.4 \pm 0.2$ \\
syrC & $16.3 \pm 1.6$ & $1.8 \pm 0.1$ \\
sypA & $4.3 \pm 0.1$ & $1.0 \pm 0.2$ \\
sypB & $25.7 \pm 2.0$ & $3.4 \pm 1.0$ \\
hrpR & $13.7 \pm 2.1$ & $11.5 \pm 2.7$ \\
hrpZ & $6.0 \pm 0.5$ & $5.7 \pm 0.4$ \\
recA & $1.2 \pm 0$ & $1.0 \pm 0$ \\
\hline
\end{tabular}

${ }^{\mathrm{z}}$ Values represent the fold change in transcriptional level for strains grown on syringomycin minimal medium (SRM) supplemented with $100 \mu \mathrm{M}$ arbutin and $0.1 \%$ D-fructose $\left(\mathrm{SRM}_{\mathrm{AF}}\right)$ compared with growth on SRM. Each value represents the average of three independent assays followed by the standard error (SE) of the mean. 
1.4-, and 1.8-fold compared with 4.3-, 25.7-, 8.4-, and 16.3fold increases by B301D, respectively (Table 3). There was no significant difference in the expression of $h r p R$ and $h r p Z$ between strains B301D and B301DG12 (Table 3). These data suggest that the plant signal transduction pathway responsible for toxin production is independent of that for the Hrp type III secretion system in B301D. In contrast, the expression of the housekeeping gene $r e c A$ was not affected by the gacS mutation. The expression of the $\operatorname{rec} A$ gene was comparable to that of B301D grown on $\mathrm{SRM}$ or $\mathrm{SRM}_{\mathrm{AF}}$ media.

\section{DISCUSSION}

The induction of toxigenesis in $P$. syringae pv. syringae by specific plant signal molecules reflects an ability of the bacterium to adapt to a dynamic plant environment. It was reported that syringomycin production is activated by specific plant signal molecules in diverse strains of $P$. syringae pv. syringae (Quigley and Gross 1994). This study established that plant signal molecules likewise control expression of genes involved in syringopeptin production based on the following evidence: i) syringopeptin production by B3AR132 and BR132 was increased more than 1.6-fold by addition of arbutin and D-fructose to SRM agar medium as revealed by bioassays; ii) GUS assays indicated that expression of sypA::uidA is increased substantially by addition of specific phenolic glycosides (i.e., arbutin, phenyl- $\beta$-Dglucopyranoside, and salicin) to SRM liquid medium; iii) analysis with a subgenomic 70-mer oligonucleotide microarray demonstrated that the transcriptional levels of the syr-syp genes are activated 2.5- to 10.5-fold by arbutin and D-fructose; and iv) QRT-PCR analysis showed that the expression of the representative syr-syp genes is induced between 4.3- and 25.7-fold by arbutin and D-fructose. This is the first report that syringopeptin production and genes involved in syringopeptin production are activated by specific plant signal molecules.

Plant signal molecules have the same specificity for induction of the syp genes as that for the syr genes. Of the 10 phenolic compounds tested, only arbutin, salicin, and phenyl- $\beta$-Dglucopyranoside showed significant induction of expression of sypA::uidA in B301DSL29. As observed for syrB1 (Mo and Gross 1991), other representative phenolic compounds (hydroquinone, naringenin, phenol, phenyl- $\beta$-D-galactopyranoside, quercetin, rutin, and saligenin) did not affect the expression of sypA::uidA. In addition, specific sugars, such as D-fructose, enhanced phenolic glycoside-mediated induction of sypA at levels similarly observed for $s y r B 1$. The similar specificity of induction of the $s y r B 1$ and sypA synthetase genes by plant signal molecules is consistent with the fact that the SalA regulon $(\mathrm{Lu}$ et al. 2005) transduces the plant signals to the syr-syp genes. The efficient induction of $s y r B 1$ and $s y p A$ genes by phenolic compounds and sugars resembles the process of vir gene activation in A. tumefaciens even though the active phenolic metabolites are different for the two bacteria (Ankenbauer and Nester 1990; Cangelosi et al. 1990; Shimoda et al. 1990). A. tumefaciens responds to acetosyringone (Stachel et al. 1985) to induce vir gene expression, whereas $P$. syringae pv. syringae responds to phenolic $\beta$-glycosides such as arbutin and salicin to activate the expression of syringomycin- and syringopeptinassociated genes. The phenolic $\beta$-glycosides are found in leaves, bark, and flowers of many plant species that are hosts of P. syringae pv. syringae (Mo and Gross 1991). Arbutin occurs in one monocot family, Liliaceae, and more than 10 dicot families, including Rosaceae, Leguminosae, and Saxifragaceae, which all are hosts of $P$. syringae pv. syringae (Mo and Gross 1991). The phenolic compounds can occur in high concentrations in plant tissues. For example, pear (Pyrus comunis) leaves contain approximately $150 \mathrm{mM}$ arbutin (Mo et al. 1995). In addition, fructose and sucrose composed as much as 1 to $3 \%$ of the dry weight of the cherry tissues (Keller and Loescher 1989). It appears that plant signal molecules would be present in sufficient quantity to induce syringomycin and syringopeptin production by Pseudomonas syringae pv. syringae in the invasion of plants as indicated by the substantial induction of $\operatorname{syr} B:$ : lacZ (Mo and Gross 1991) and sypA::uidA by arbutin $(100 \mu \mathrm{M})$ and D-fructose $(0.1 \%)$.

Microarray analysis is a powerful tool for monitoring expression of the syr-syp genes (Lu et al. 2005; Rhodius and LaRossa 2003). Analysis with 70-mer oligonucleotide subgenomic microarrays indicates that plant signal molecules induce the coordinated expression of the syr-syp genes. Once the effects of arbutin and D-fructose on syringomycin and syringopeptin production in B301D were established, microarray analysis was used to examine the signal activity of arbutin and D-fructose on expression of virulence-associated genes. It was shown clearly in the microarray analysis that not only are the toxin biosynthesis genes positively regulated, but regulatory and secretion genes associated with syringomycin and syringopeptin production also are induced by arbutin and D-fructose. The upregulated syr-syp genes belong to the SalA regulon ( $\mathrm{Lu}$ et al. 2005) as indicated by clustering analysis (Fig. 4), which demonstrates that the plant signal transduction of the syr-syp genes is mediated by SalA. It appears that cluster analysis is very useful in identifying specific pathways that are co-regulated based on their similar patterns of gene expression (Bolshakova and Azuaje 2003).

In addition to the induction of syringomycin and syringopeptin, most hrp and $a v r$ genes included in this study were induced by the addition of arbutin and D-fructose. The induction of $h r p$ and $a v r$ genes was reported to commonly occur in plant-bacteria interactions (Boch et al. 2002; Rahme et al. 1992). Induction of hrp genes was studied mostly in planta, and the specific plant signal molecules involved in induction were not defined (Rahme et al. 1992). The hrp genes were shown to be expressed when bacteria were grown in defined minimal medium but not in complex media and could be induced four- to sixfold when transferred from King's B medium to M63M medium (Arlat et al. 1992; Hendrickson et al. 2001; Rahme et al. 1992; Wei et al. 1992; Xiao et al. 1992). The SRM used in this study is different from the defined hrp-inducing medium and supports the expression of the hrp genes tested. The transcriptional levels of $h r p Z, h r p W, h r p L, h r p R$, and $h r p K$ were increased from two- to fourfold in $\mathrm{SRM}_{\mathrm{AF}}$ liquid medium, which demonstrates a link between plant signal molecules that induce phytotoxin production and genes associated with the Hrp type III secretion system.

Despite the fact that syr-syp and hrp/avr genes are activated by plant signal molecules, the two systems use different signal transduction pathways to induce virulence-associated genes. The plant signal stimulon might involve the coordinated expression of numerous regulons, a situation similar to that of the heat shock stimulon (Narberhaus 1999; Yura and Nakahigashi 1999). As observed by cluster analysis (Fig. 4), the induced genes were grouped into the syr-syp and the hrp/avr clusters. The syr-syp genes were demonstrated to belong to the SalA regulon (Lu et al. 2005), whereas the hrp/avr genes were clustered together and belong to the HrpL regulon (Fouts et al. 2002). In P. syringae, three regulatory genes, $h r p L, h r p R$, and $h r p S$, are dedicated to hrp/avr gene expression (Fig. 5) (Grimm et al. 1995; Hutcheson et al. 2001; Xiao and Hutcheson 1994). Considerable research has been done to verify the relationship between $h r p$ and GacS/GacA systems (Chatterjee et al. 2003). RT-PCR transcriptional analysis revealed that a $P$. syringae gacS mutation abolished induction of the four syringomycin/syringopeptin synthesis genes $s y r B 1, \operatorname{syr} C$, sypA, and sypB by plant signal molecules 
(Table 3). However, the induction of $h r p R$ and $h r p Z$ by plant signal molecules is not affected by mutation of gacS. This is consistent with the discovery that GacA does not control hrp genes in P. syringae pv. syringae B728a (Chatterjee et al. 2003). Thus, the plant signal induction of syringomycin and syringopeptin in B301D is via the GacS/A pathway, whereas the induction of the hrp genes uses a different pathway.

Both the salA and $s y r F$ regulatory genes are required for syringopeptin production. It has been demonstrated that the regulation of syringopeptin and syringomycin is controlled by the same regulatory cascade. SalA is the key regulator in the control of syringomycin and syringopeptin production ( $\mathrm{Lu}$ et al. 2002, 2005). SyrF, which is controlled by SalA, positively regulates syringomycin production (Lu et al. 2002) and this study demonstrated that SyrF positively regulates syringopeptin production (Fig. 3). Standard phytotoxin bioassays showed that disruption of either salA or syrF resulted in the failure to produce syringopeptin on both SRM and $\mathrm{SRM}_{\mathrm{AF}}$ agar media 4 days after inoculation (Fig. 3). Furthermore, the expression of sypA::uidA in either salA or syrF mutants was substantially decreased compared with that of B301D grown in SRM and $\mathrm{SRM}_{\mathrm{AF}}$ liquid media, respectively. Both SalA and SyrF belong to the LuxR regulatory protein family (Kaiser and Losick 1993; Lu et al. 2002). The LuxR protein contains a helix-turn-helix DNA-binding motif at the $\mathrm{C}$ terminus and regulates target genes by binding to the lux box in the promoter regions (Egland and Greenberg 1999). It appears that SyrF controls the coordinated expression of the syr-syp genes by binding to the promoter regions directly (Wang et al. 2006).
Microarray analysis of the plant signal stimulon in $P$. syringae pv. syringae provides a valuable foundation for the study of the regulatory mechanism controlling syringomycin and syringopeptin production. Apparently, the bacterium coordinates the expression of the syr-syp and hrp genes in response to the plant environment (Fig. 5). As proposed in the model shown in Figure 5, P. syringae pv. syringae senses plant signal molecules via the GacS/A pathway, which then activates the expression of the syr-syp genes through SalA and SyrF. It remains to be determined what genes are directly involved in the sensing of plant signal molecules and how SyrF controls syringomycin and syringopeptin production. It is expected that SyrF might control the coordinated expression of the syr-syp genes by directly binding to the promoters, as suggested in the model proposed in Figure 5. Currently, the promoter regions of the syrsyp genes (Wang et al. 2006) and the functions of SyrF and SalA regulatory proteins are being characterized in an effort to understand the co-regulatory mechanism important for syringomycin and syringopeptin production.

\section{MATERIALS AND METHODS}

Bacterial strains, plasmids, and media.

The bacterial strains and plasmids used in this study are listed in Table 4. The Escherichia coli DH10B (Sawahel et al. 1993) used for cloning was cultured at $37^{\circ} \mathrm{C}$ in Terrific Broth (TB) or on Luria-Bertani (LB) agar media. Strains of $P$. syringae pv. syringae were cultured routinely at $25^{\circ} \mathrm{C}$ in nutrient broth-yeast extract (NBY) liquid or agar medium (Vidaver 1967). To evaluate the effect of plant signal molecules on in-

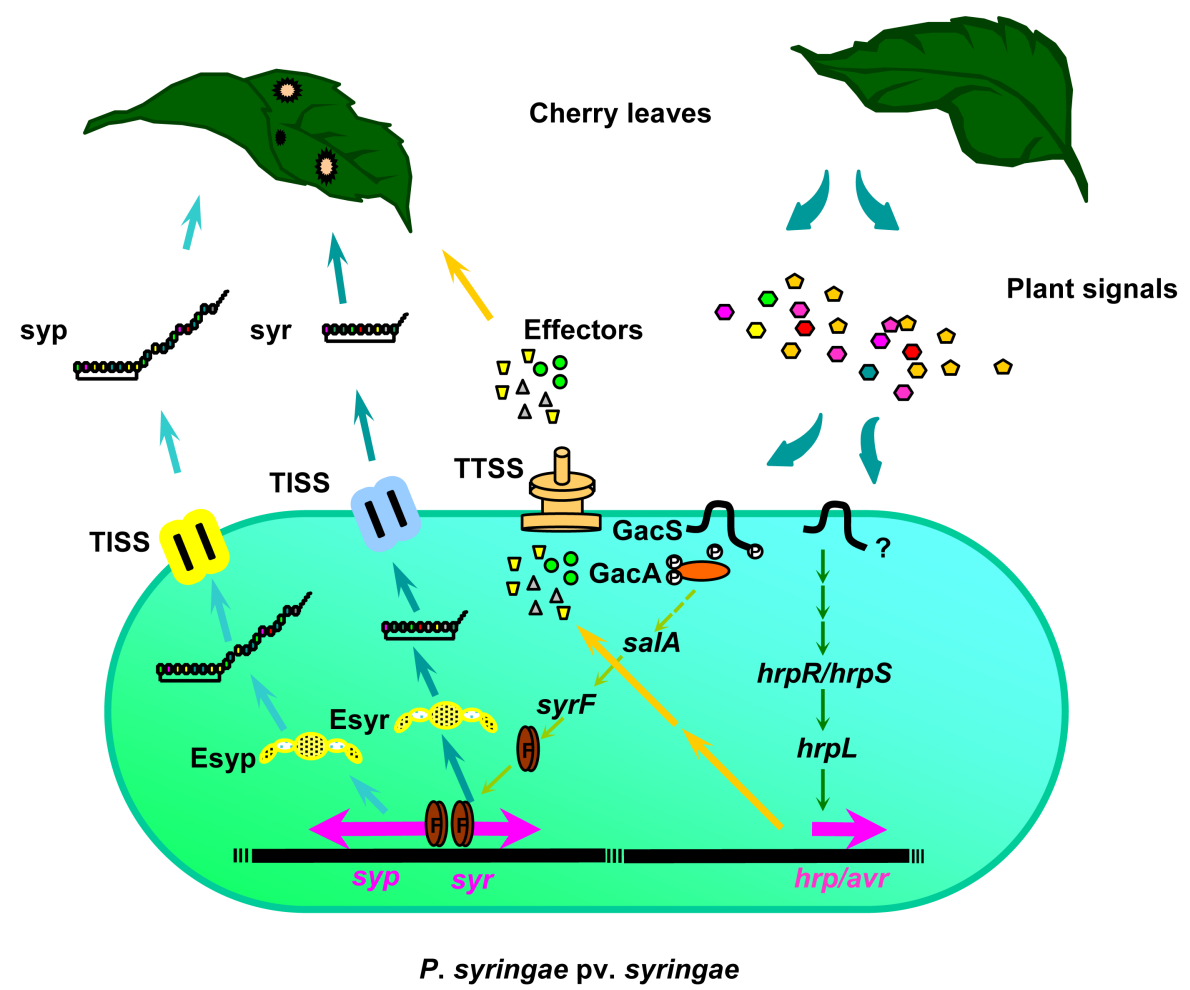

Fig. 5. Diagram of the stimulon induced by plant signal molecules in Pseudomonas syringae pv. syringae B301D to activate phytotoxin production. Plant signal molecules in the plant apoplast activate the gacS/gacA, salA, syrF, and $h r p L$ signal transduction pathways leading to the transcription of the syr-syp toxin genes and genes associated with Hrp type III secretion (TTSS). Strain B301D senses plant signals by GacS, a transmembrane sensor kinase, or some unknown acceptor senses the plant signals and transfers them to GacS. GacS then activates salA through the response regulator GacA. SalA transcriptionally activates expression of $s y r F$ and SyrF, in turn, activates the syr-syp genes upon binding to the promoter region as a dimer. B301D also senses plant signal molecules through an unknown mechanism (represented as ?) to activate expression of the Hrp type III associated genes through the $h r p R / h r p S / h r p L$ regulatory pathway. Expression of syringomycin (syr) and syringopeptin (syp) genes is induced by plant signal molecules, and the toxins are secreted through a type I secretion system (TISS). The nonribosomal peptide synthetases for syr and syp are represented as Esyr and Esyp, respectively. 
duction of syringopeptin production, syringomycin minimal SRM and $\mathrm{SRM}_{\mathrm{AF}}$ (SRM containing $100 \mu \mathrm{M}$ arbutin and $0.1 \%$ fructose) media were prepared as described previously (Mo and Gross 1991). For tests of gene induction by plant signal molecules, $P$. syringae pv. syringae was cultured in SRM (Mo and Gross 1991) liquid or agar medium with or without plant signal molecules as identified below. Antibiotics (SigmaAldrich, St. Louis, U.S.A.) were added to media in the following concentrations: tetracycline, $25 \mu \mathrm{g} / \mathrm{ml}$ Km, $100 \mu \mathrm{g} / \mathrm{ml}$; ampicillin, $100 \mu \mathrm{g} / \mathrm{ml}$; and gentamicin, $5 \mu \mathrm{g} / \mathrm{ml}$.

\section{Bioassays for syringopeptin production.}

The $P$. syringae pv. syringae strains BR132 and B3AR132 were evaluated for syringopeptin production on SRM and $\mathrm{SRM}_{\mathrm{AF}}$ media by using standard bioassays as previously described by Scholz-Schroeder and associates (2001a). Briefly, $P$. syringae pv. syringae strains were grown overnight in $2 \mathrm{ml}$ of NBY liquid medium. Bacterial cells were harvested by centrifugation, washed once with sterile distilled water (SDW), and then resuspended in SDW to a concentration of approximately $2 \times 10^{8} \mathrm{CFU} / \mathrm{ml}$. Aliquots $(5 \mu \mathrm{l})$ of bacterial suspension were spotted onto SRM and $\mathrm{SRM}_{\mathrm{AF}}$ plates. The strains were cultured on plates for 4 days and then sprayed with $B$. megaterium $\mathrm{Km}$ and cultured overnight at $25^{\circ} \mathrm{C}$. Because syringomycin inhibits the growth of $B$. megaterium, both strains tested for syringopeptin production were $s y r B 1$ mutants (i.e., BR132 and B3AR132) (Scholz-Schroeder et al. 2001a). Duplicate cultures were prepared for all treatments with all assays repeated three times on separate days.
Construction of GUS transcriptional fusions and procedures for GUS assays.

The regulatory effects of salA and $s y r F$ genes on expression of the sypA::uidA gene fusion in cis were quantified by fluorometric analysis of GUS activity. Plasmid pSL19, which carries a disrupted $s y r F$ gene by insertion of the nptII cassette, was electroporated into the sypA::uidA reporter strain B301DSL29 (Lu et al. 2005) to generate the double mutant B301DNW31. The disrupted $s y r F$ gene in the double mutant was amplified by PCR. Primers used in the amplification of $s y r F$ were PsyrFf: GCCATTCCTTGCGCCCATAAA and PsyrFr: CGAG GCAGAATTCCGACACAAG. The resulting PCR product from B301DNW31 was subcloned into the pGEM-T easy vector to generate plasmid pNWE32. The insertion of the nptII cassette into $\operatorname{syr} F$ was confirmed by sequencing using PsyrFf as the primer.

The effects of different plant signal molecules and regulatory genes (i.e., salA, syrF, and $s y r G$ ) on expression of syrB1::uidA and sypA::uidA gene fusions were quantified by fluorometric tests of GUS activity. A modified fluorometric protocol was used for analysis of GUS activity (Lu et al. 2002). Bacterial cells were cultured with shaking in $2 \mathrm{ml}$ of NBY broth overnight at $25^{\circ} \mathrm{C}$, harvested by centrifugation, washed twice with SDW, and then diluted with $20 \%$ glycerol to an optical density of 0.6 at $600 \mathrm{~nm}$. Stock cell suspensions were stored at $-80^{\circ} \mathrm{C}$. Cell stock suspensions $(50 \mu \mathrm{l})$ were used to inoculate $4 \mathrm{ml}$ of potato dextrose broth medium or SRM liquid medium with or without plant signal molecules and incubated for $72 \mathrm{~h}$ at $25^{\circ} \mathrm{C}$ without shaking. Cell cultures $(50 \mu \mathrm{l})$

Table 4. Strains and plasmids

\begin{tabular}{|c|c|c|}
\hline Strain or plasmid & Relevant characteristics $^{\mathrm{z}}$ & Source \\
\hline \multicolumn{3}{|l|}{ Escherichia coli } \\
\hline DH10B & $\begin{array}{l}\text { F mcrA } \Delta l a c X 74(\phi 80 \mathrm{~d} l a c Z \Delta \mathrm{M} 15) \Delta(\mathrm{mrr}-\mathrm{hs} d R M S-m c r B) \text { deoR recA1 endA1 araD139 } \\
\Delta(\text { ara, leu }) 7697 \text { galU galK } \lambda^{-} \text {rpsL nupG }\end{array}$ & Grant et al. 1990 \\
\hline \multicolumn{3}{|c|}{ Pseudomonas syringae pv. syringae } \\
\hline B301D & Wild type, from pear & Cody and Gross 1987 \\
\hline B301DG12 & gacS::nptII derivative of $\mathrm{B} 301 \mathrm{D} ; \mathrm{Km}^{\mathrm{r}}$ & Kang and Gross 2005 \\
\hline B301DSL1 & syrF ::nptII derivative of B301D; $\mathrm{Km}^{\mathrm{r}}$ & Lu et al. 2002 \\
\hline B301DSL7 & salA::nptII derivative of $\mathrm{B} 301 \mathrm{D} ; \mathrm{Km}^{\mathrm{r}}$ & Lu et al. 2002 \\
\hline B301DSL6 & syrG::nptII derivative of $\mathrm{B} 301 \mathrm{D} ; \mathrm{Km}^{\mathrm{r}}$ & Lu et al. 2002 \\
\hline B301DSL8 & syrB1::uidA-aaaC1, derivative of B301D; $\mathrm{Gm}^{\mathrm{r}}$ & Lu et al. 2002 \\
\hline B301DSL29 & sypA::uidA-aaaC1, derivative of B301D; $\mathrm{Gm}^{\mathrm{r}}$ & Lu et al. 2005 \\
\hline B301DSL30 & salA::nptII derivative of B301DSL29; $\mathrm{Gm}^{\mathrm{r}} \mathrm{Km}^{\mathrm{r}}$ & Lu et al. 2002 \\
\hline B301DNW31 & syrF::nptII derivative of B301DSL29; $\mathrm{Gm}^{\mathrm{r}} \mathrm{Km}^{\mathrm{r}}$ & This study \\
\hline BR132 & syrB1::Tn3HoHol derivative of B301D-R; Pip $^{\mathrm{r}} \mathrm{Rif}^{\mathrm{r}}$ & Mo and Gross 1991 \\
\hline B3A & Wild type & Mo and Gross 1991 \\
\hline B3AR132 & syrB1::Tn3HoHol derivative of B3A-R; Pip $^{\mathrm{r}} \mathrm{Rif}^{\mathrm{r}}$ & Mo and Gross 1991 \\
\hline \multicolumn{3}{|l|}{ Plasmid } \\
\hline pBluescriptSK(+) & Cloning vector; $\mathrm{Ap}^{\mathrm{r}}$ & Stratagene. La Jolla, CA \\
\hline pUCP26 & Cloning vector; $\mathrm{Tc}^{\mathrm{r}} \mathrm{Ap}^{\mathrm{r}}$ & West et al. 1994 \\
\hline pBR325 & Cloning vector; $\mathrm{Cm}^{\mathrm{r}} \mathrm{Tc}^{\mathrm{r}} \mathrm{Ap}^{\mathrm{r}}$ & Prentki et al. 1981 \\
\hline pLAFR3 & Cloning vector; $\mathrm{Tc}^{\mathrm{r}}$ & Staskawicz et al. 1987 \\
\hline pNWE32 & pGEM-T easy carrying syrF::nptII cloned from B301DNW31 & This study \\
\hline p29 & pLAFR3 carrying a 16-kb fragment of B301D genomic DNA; $\mathrm{Tc}^{\mathrm{r}}$ & Lu et al. 2002 \\
\hline pSL2 & $\begin{array}{l}\text { pBI101 with the } 0.85-\mathrm{kb} \text { aac } C 1 \text { gene of pUCGM inserted at the EcoRI site downstream of } \\
\text { the uidA gene; } \mathrm{Km}^{\mathrm{r}} \mathrm{Gm}^{\mathrm{r}}\end{array}$ & Lu et al. 2002 \\
\hline pSL19 & $\begin{array}{l}\text { pBR325 carrying the } 5.8-\mathrm{kb} \text { BamHI-KpnI fragment of p29 with } n p t I I \text { insertion at BstEII } \\
\text { site of syrF; } \mathrm{Ap}^{\mathrm{r}} \mathrm{Tc}^{\mathrm{r}} \mathrm{Km}^{\mathrm{r}}\end{array}$ & Lu et al. 2002 \\
\hline pSL9 & $\begin{array}{l}\text { pBluescriptSK(+) carrying a 2.5-kb HindIII-EcoRV fragment of pSL5 containing syrG; } \\
\mathrm{Ap}^{\mathrm{r}}\end{array}$ & Lu et al. 2002 \\
\hline pSL40F & $\begin{array}{l}\text { pLAFR } 3 \text { carrying the } 3.0-\mathrm{kb} E c o \mathrm{RI} \text { fragment of } \mathrm{p} 29 \text { with the } 3.2-\mathrm{kb} \text { uidA-aacCl fragment } \\
\text { from pSL } 2 \text { inserted at the KpnI site in-frame of } s a l A \text { in forward orientation; } \mathrm{Tc}^{\mathrm{r}} \mathrm{Gm}^{\mathrm{r}}\end{array}$ & Lu et al. 2002 \\
\hline pSL39F & $\begin{array}{l}\text { pLAFR3 carrying the } 2.5-\mathrm{kb} \text { HindIII-EcoRV fragment of pSL9 with the } 3.2-\mathrm{kb} \text { uidA- } \\
\text { aacC1 fragment from pSL2 inserted at the EcoRI site in-frame of syrG in forward } \\
\text { orientation; } \mathrm{Tc}^{\mathrm{r}} \mathrm{Gm}^{\mathrm{r}}\end{array}$ & Lu et al. 2002 \\
\hline pSL38F & $\begin{array}{l}\text { pLAFR3 carrying the } 5.8-\mathrm{kb} \text { BamHI-KpnI fragment of p } 29 \text { with the } 3.2-\mathrm{kb} \text { uidA-aacC1 } \\
\text { fragment from pSL2 inserted at the BstEII site in-frame of } s y r F \text { in forward orientation; } \\
\mathrm{Tc}^{\mathrm{r}} \mathrm{Gm}^{\mathrm{r}}\end{array}$ & Lu et al. 2002 \\
\hline
\end{tabular}

${ }^{\mathrm{z}} \mathrm{Km}^{\mathrm{r}}, \mathrm{Gm}^{\mathrm{r}}, \mathrm{Pip}^{\mathrm{r}}, \mathrm{Rif}^{\mathrm{r}}, \mathrm{Tc}^{\mathrm{r}}, \mathrm{Ap}^{\mathrm{r}}$, and $\mathrm{Cm}^{\mathrm{r}}$ indicate resistance to kanamycin, gentamicin, piperacillin, rifampicin, tetracycline, ampicillin, chloramphenicol, respectively. 
Table 5. Primers used for quantitative real-time polymerase chain reaction analysis

\begin{tabular}{|c|c|c|}
\hline Name & Sequence & Resource \\
\hline sypAF & TGCGGGTCGAGGCGTTTTTG & Kang and Gross 2005 \\
\hline sypAR & GTTGCCGCGTCCTTGTCTGA & Kang and Gross 2005 \\
\hline sypBF & TTCGATCAGGGTCACCGCCAACAATG & Lu et al. 2005 \\
\hline sypBR & AGCTGCTCAATGTCGAAAAGGTC & Lu et al. 2005 \\
\hline syrB1F & TTAGCGCCGCGTCAGCCCCTCTCAAG & Kang and Gross 2005 \\
\hline syrB1R & GCTCAACGTCCGGGCTGCATCGCTCA & Kang and Gross 2005 \\
\hline syrCF & ACCTGCAAGCGATGTTCCTC & Lu et al. 2005 \\
\hline syrCR & TGCCAGCTCGGTCTTGTTCA & Lu et al. 2005 \\
\hline hrpRF & TTCGGCGTGGTCAATGGTGCGTTCA & This study \\
\hline hrpRR & CGTGTCGATTTCGTCCAGATAGAGG & This study \\
\hline hrpZF & TCCTGAAACCGAGACGACTGG & This study \\
\hline hrpZR & GACCGTTGCGCATCAGTTCCTC & This study \\
\hline recAF & CTTCGGTACGCCTGGACA & Lu et al. 2005 \\
\hline recAR & AACTCGGCCTGACGGAAC & Lu et al. 2005 \\
\hline $16 \mathrm{SF}$ & ACACCGCCCGT CACACCA & Lu et al. 2005 \\
\hline 16SR & GTTCCCCTACGGCTACCTT & Lu et al. 2005 \\
\hline
\end{tabular}

were collected by centrifugation, resuspended in $100 \mu \mathrm{l}$ of GUS extract buffer (Xiao et al. 1992), and lysed by sonication. Duplicate cultures were prepared for GUS assays with all assays repeated three times on separate days.

\section{Phenolic compounds, sugars, and organic acids tested for $\operatorname{syp} A$-inducing activity.}

Phenolic compounds tested for plant signal activity were arbutin (ICN Biomedicals Inc., Aurora, OH, U.S.A.), hydroquinone, naringenin, phenol, phenyl- $\beta$-D-glucopyranoside, phenyl$\beta$-D-galactopyranoside, quercetin, rutin, salicin, and saligenin (Sigma-Aldrich). D-fructose, which is known to enhance the signal activities of phenolic compounds (Mo and Gross 1991), was purchased from Baker Chem. Co. (Phillipsburg, NJ, U.S.A.).

\section{Microarray analysis.}

To test the effects of arbutin and D-fructose on the expression of syr-syp genes and genes involved in production of factors associated with plant pathogenesis, microarray analysis was performed as described recently (Lu et al. 2005). Strains of $P$. syringae pv. syringae were cultured with shaking at $25^{\circ} \mathrm{C}$ overnight in NBY medium $(2 \mathrm{ml})$. Cells were harvested by centrifugation, washed twice, and then diluted with SDW to a concentration of approximately $2 \times 10^{8} \mathrm{CFU} / \mathrm{ml}$. Cell suspensions $(50 \mu \mathrm{l})$ were spread on SRM and $\mathrm{SRM}_{\mathrm{AF}}$ plates. The inoculated plates were incubated at $25^{\circ} \mathrm{C}$ for $72 \mathrm{~h}$ prior to recovery of cells. Total RNA was purified using a RiboPure-Bacteria kit (Ambion, Inc., Austin, TX, U.S.A.). Total RNA $(50 \mu \mathrm{g})$ was labeled with either Cy3-dUTP or Cy5-dUTP as described previously ( $\mathrm{Lu}$ et al. 2005). Glass DNA microarrays containing a set of 70-mer oligonucleotides ( $\mathrm{Lu}$ et al. 2005), designed and synthesized by Qiagen (now available at Operon Biotechnologies, Inc., Huntsville, AL, U.S.A.), were produced to represent genes contained in the syr-syp genomic island and other genes associated with virulence. The microarrays were used to quantify relative mRNA levels by parallel two-color hybridization according to protocols described in detail elsewhere ( $\mathrm{Lu}$ et al. 2005). Briefly, hybridization was performed at $60^{\circ} \mathrm{C}$ overnight in a moist chamber. After washing, the slides were dried by centrifugation and scanned immediately using a GenePix 4000b scanner (Axon Instruments Inc., Foster City, CA, U.S.A.) to visualize the hybridization images.

Signal intensity and ratios were generated using GenePix Pro software provided with the scanner. Microarray data with intensities reproducibly higher than that of the background level were selected for analysis. The raw data was normalized using 16S rRNA as a standard. Hybridization experiments were conducted three times and each slide contained duplicate arrays.

\section{Hierarchical clustering.}

Unsupervised hierarchical clustering analysis of syr-syp and relevant genes was performed with SOTA. Cluster analysis was visualized with Treeview software (Rhodes et al. 2002).

\section{QRT-PCR analysis.}

The effect of arbutin and fructose on $\operatorname{syr} C, \operatorname{syp} B, h r p R$, $h r p Z$, and inaK observed in microarray analysis was evaluated by QRT-PCR using the QuantiTect SYBR Green RT-PCR kit (Qiagen Inc., Valencia, CA, U.S.A.). QRT-PCR also was used to assess the effect of disruption of the $g a c S$ global regulatory gene on expression of the $s y r C$, sypB, hrpR, and hrpZ genes. Primers used for RT-PCR were designed using the Lasergene Expert Sequence Analysis Package (DNAstar, Madison, WI, U.S.A.) and are listed in Table 5. Consistent with microarray analysis, primers specific for the 16S rRNA gene were used for normalization controls. The linearity of detection of each primer pair was confirmed to have a correlation coefficient of at least $0.98\left(\mathrm{r}^{2}>0.98\right)$ over the detection area by measuring a fivefold dilution curve with total RNA isolated from bacterial cells. Reverse transcription was conducted at $50^{\circ} \mathrm{C}$ for $30 \mathrm{~min}$ with $100 \mathrm{ng}$ of total RNA as template, then followed by initial activation of HotStarTaq DNA Polymerase $\left(95^{\circ} \mathrm{C}, 15 \mathrm{~min}\right)$. Totally, 30 cycles of RT-PCR reactions $\left(94^{\circ} \mathrm{C}\right.$ for $15 \mathrm{~s}, 55^{\circ} \mathrm{C}$ for $30 \mathrm{~s}$, and $72^{\circ} \mathrm{C}$ for $30 \mathrm{~s}$ ) were performed followed by melting curve analysis.

\section{ACKNOWLEDGMENTS}

This work was supported by grant 2001-35319-10400 from the National Research Competitive Grants Program of the United States Department of Agriculture, Science, and Education Administration. We thank Angela Records for critical reading of this manuscript.

\section{LITERATURE CITED}

Alarcón-Chaidez, F. J., Keith, L., Zhao, Y. F., and Bender, C. L. 2003. $\operatorname{RpoN}\left(\sigma^{54}\right)$ is required for plasmid-encoded coronatine biosynthesis in Pseudomonas syringae. Plasmid 49:106-117.

Alfano, J. R., Charkowski, A. O., Deng, W. L., Badel, J. L., PetnickiOcwieja, T., van Dijk, K., and Collmer, A. 2000. The Pseudomonas syringae Hrp pathogenicity island has a tripartite mosaic structure composed of a cluster of type III secretion genes bounded by exchangeable effector and conserved effector loci that contribute to parasitic fitness and pathogenicity in plants. Proc. Natl. Acad. Sci. U.S.A. 97:48564861.

Amrein, H., Makart, S., Granado, J., Shakya, R., Schneider-Pokorny, J., and Dudler, R. 2004. Functional analysis of genes involved in the synthesis of syringolin A by Pseudomonas syringae pv. syringae B301D-R. Mol. Plant-Microbe Interact. 17:90-97.

Ankenbauer, R. G., and Nester, E. W. 1990. Sugar-mediated induction of 
Agrobacterium tumefaciens virulence genes-structural specificity and activities of monosaccharides. J. Bacteriol. 172:6442-6446.

Arlat, M., Gough, C. L., Zischek, C., Barberis, P. A., Trigalet, A., and Boucher, C. A. 1992. Transcriptional organization and expression of the large hrp gene cluster of Pseudomonas solanacearum. Mol. PlantMicrobe Interact. 5:187-193.

Beaulieu, C., Boccara, M., and Van Gijsegem, F. 1993. Pathogenic behavior of pectinase-defective Erwinia chrysanthemi mutants on different plants. Mol. Plant-Microbe Interact. 6:197-202.

Boch, J., Joardar, V., Gao, L., Robertson, T. L., Lim, M., and Kunkel, B. N. 2002. Identification of Pseudomonas syringae pv. tomato genes induced during infection of Arabidopsis thaliana. Mol. Microbiol. 44:7388.

Bolshakova, N., and Azuaje, F. 2003. Cluster validation techniques for genome expression data. Signal Process. 83:825-833.

Brinkman, F. S. L., Schoofs, G., Hancock, R. E. W., and De Mot, R. 1999. Influence of a putative ECF sigma factor on expression of the major outer membrane protein, OprF, in Pseudomonas aeruginosa and Pseudomonas fluorescens. J. Bacteriol. 181:4746-4754.

Cangelosi, G. A., Ankenbauer, R. G., and Nester, E. W. 1990. Sugars induce the Agrobacterium virulence genes through a periplasmic bindingprotein and a transmembrane signal protein. Proc. Natl. Acad. Sci. U.S.A. 87:6708-6712.

Chancey, S. T., Wood, D. W., and Pierson, L. S. 1999. Two-component transcriptional regulation of $\mathrm{N}$-acyl-homoserine lactone production in Pseudomonas aureofaciens. Appl. Environ. Microbiol. 65:2294-2299.

Charkowski, A. O., Alfano, J. R., Preston, G., Yuan, J., He, S. Y., and Collmer, A. 1998. The Pseudomonas syringae pv. tomato HrpW protein has domains similar to harpins and pectate lyases and can elicit the plant hypersensitive response and bind to pectate. J. Bacteriol 180:5211-5217.

Chatterjee, A., Cui, Y. Y., Yang, H. L., Collmer, A., Alfano, J. R., and Chatterjee, A. K. 2003. GacA, the response regulator of a two-component system, acts as a master regulator in Pseudomonas syringae pv. tomato DC3000 by controlling regulatory RNA, transcriptional activators, and alternate sigma factors. Mol. Plant-Microbe Interact. 16:1106-1117.

Cody, Y. S., and Gross, D. C. 1987. Characterization of pyoverdin ${ }_{\mathrm{pss}}$, the fluorescent siderophore produced by Pseudomonas syringae pv. syringae. Appl. Environ. Microbiol. 53:928-934.

Collmer, A., Badel, J. L., Charkowski, A. O., Deng, W. L., Fouts, D. E. Ramos, A. R., Rehm, A. H., Anderson, D. M., Schneewind, O., van Dijk, K., and Alfano, J. R. 2000. Pseudomonas syringae Hrp type III secretion system and effector proteins. Proc. Natl. Acad. Sci. U.S.A. 97:8770-8777.

Corbell, N., and Loper, J. E. 1995. A global regulator of secondary metabolite production in Pseudomonas fluorescens Pf-5. J. Bacteriol. 177:6230-6236.

Coronado, C., Vazquez, M. E., Cebolla, A., and Palomares, A. J. 1994. Use of firefly luciferase gene for plasmid copy number determination. Plasmid 32:336-341.

Cui, Y., Chatterjee, A., and Chatterjee, A. K. 2001. Effects of the two-component system comprising GacA and GacS of Erwinia carotovora subsp. carotovora on the production of global regulatory rsmB RNA,

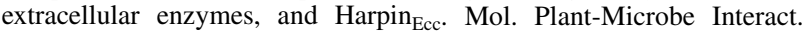
14:516-526.

Egland, K. A., and Greenberg, E. P. 1999. Quorum sensing in Vibrio fischeri: elements of the luxl promoter. Mol. Microbiol. 31:1197-1204.

Fakhr, M. K., Peñaloza-Vázquez, A, Chakrabarty, A. M., and Bender, C. L. 1999. Regulation of alginate biosynthesis in Pseudomonas syringae pv. syringae. J. Bacteriol. 181:3478-3485.

Fouts, D. E., Abramovitch, R. B., Alfano, J. R., Baldo, A. M., Buell, C. R., Cartinhour, S., Chatterjee, A. K., D’Ascenzo, M., Gwinn, M. L., Lazarowitz, S. G., Lin, N. C., Martin, G. B., Rehm, A. H., Schneider, D. J., van Dijk, K., Tang, X. Y., and Collmer, A. 2002. Genomewide identification of Pseudomonas syringae pv. tomato DC3000 promoters controlled by the HrpL alternative sigma factor. Proc. Natl. Acad. Sci. U.S.A. 99:2275-2280.

Franza, T., Mahé, B., and Expert, D. 2005. Erwinia chrysanthemi requires a second iron transport route dependent of the siderophore achromobactin for extracellular growth and plant infection. Mol. Microbiol. 55:261275

Grant, S. G. N., Jessee, J., Bloom, F. R., and Hanahan, D. 1990. Differential plasmid rescue from transgenic mouse DNAs into Escherichia coli methylation-restriction mutants. Proc. Natl. Acad. Sci. U.S.A. 87:46454649.

Grgurina, I., Gross, D. C., Iacobellis, N. S., Lavermicocca, P., Takemoto, J. Y., and Benincasa, M. 1996. Phytotoxin production by Pseudomonas syringae pv. syringae: Syringopeptin production by syr mutants defective in biosynthesis or secretion of syringomycin. FEMS (Fed. Eur. Microbiol. Soc.) Microbiol. Lett. 138:35-39.
Grimm, C., Aufsatz, W., and Panopoulos, N. J. 1995. The hrpRS locus of Pseudomonas syringae pv. phaseolicola constitutes a complex regulatory unit. Mol. Microbiol. 15:155-165.

Guenzi, E., Galli, G., Grgurina, I., Gross, D. C., and Grandi, G. 1998 Characterization of the syringomycin synthetase gene cluster: a link between prokaryotic and eukaryotic peptide synthetases. J. Biol. Chem. 273:32857-32863.

Hassett, D. J., Woodruff, W. A., Wozniak, D. J., Vasil, M. L., Cohen, M. S., and Ohman, D. E. 1993. Cloning and characterization of the Pseudomonas aeruginosa sodA and $\operatorname{sodB}$ genes encoding manganese-and iron-cofactored superoxide dismutase: demonstration of increased manganese superoxide-dismutase activity in alginate-producing bacteria. J. Bacteriol. 175:7658-7665.

Hassett, D. J., Sokol, P. A., Howell, M. L., Ma, J. F., Schweizer, H. T., Ochsner, U., and Vasil, M. L. 1996. Ferric uptake regulator (Fur) mutants of Pseudomonas aeruginosa demonstrate defective siderophore-mediated iron uptake, altered aerobic growth, and decreased superoxide dismutase and catalase activities. J. Bacteriol. 178:39964003

He, S. Y., Huang, H. C., and Collmer, A. 1993. Pseudomonas syringae pv. syringae Harpin $_{\text {Pss: }}$ a protein that is secreted via the Hrp pathway and elicits the hypersensitive response in plants. Cell 73:1255-1266.

Heeb, S., and Haas, D. 2001. Regulatory roles of the GacS/GacA twocomponent system in plant-associated and other gram-negative bacteria. Mol. Plant-Microbe Interact. 14:1351-1363.

Heeb, S., Blumer, C., and Haas, D. 2002. Regulatory RNA as mediator in GacA/RsmA-dependent global control of exoproduct formation in Pseudomonas fluorescens CHA0. J. Bacteriol. 184:1046-1056.

Hendrickson, E. L., Plotnikova, J., Mahajan-Miklos, S., Rahme, L. G., and Ausubel, F. M. 2001. Differential roles of the Pseudomonas aeruginosa PA14 rpoN gene in pathogenicity in plants, nematodes, insects, and mice. J. Bacteriol. 183:7126-7134.

Hengge-Aronis, R. 1993. Survival of hunger and stress: the role of $r p o S$ in early stationary phase gene regulation in Escherichia coli. Cell 72:165168.

Herrero, J., Valencia, A., and Dopazo, J. 2001. A hierarchical unsupervised growing neural network for clustering gene expression patterns. Bioinformatics 17:126-136.

Hrabak, E. M., and Willis, D. K. 1993. Involvement of the lemA gene in production of syringomycin and protease by Pseudomonas syringae pv. syringae. Mol. Plant-Microbe Interact. 6:368-375.

Hutcheson, S. W., Bretz, J., Sussan, T., Jin, S. M., and Pak, K. 2001. Enhancer-binding proteins HrpR and HrpS interact to regulate hrp-encoded type III protein secretion in Pseudomonas syringae strains. J. Bacteriol. 183:5589-5598.

Ikai, H., and Yamamoto, S. 1997. Identification and analysis of a gene encoding L-2,4-diaminobutyrate:2-ketoglutarate 4-aminotransferase involved in the 1,3-diaminopropane production pathway in Acinetobacter baumannii. J. Bacteriol. 179:5118-5125.

Kaiser, D., and Losick, R. 1993. How and why bacteria talk to each other. Cell 73:873-885.

Kang, H., and Gross, D. C. 2005. Characterization of a resistance-nodulation-cell division transporter system associated with the syr-syp genomic island of Pseudomonas syringae pv. syringae. Appl. Environ. Microbiol. 71:5056-5065.

Keith, L. M. W., and Bender, C. L. 1999. A1gT $\left(\sigma^{22}\right)$ controls alginate production and tolerance to environmental stress in Pseudomonas syringae. J. Bacteriol. 181:7176-7184.

Keller, J. D., and Loescher, W. H. 1989. Nonstructural carbohydrate partitioning in perennial parts of sweet cherry. J. Am. Soc. Hortic. Sci. 114:969-975

Kinscherf, T. G., and Willis, D. K. 1999. Swarming by Pseudomonas syringae $\mathrm{B} 728$ a requires gacS (lemA) and gacA but not the acyl-homoserine lactone biosynthetic gene ahlI. J. Bacteriol. 181:4133-4136.

Kitten, T., Kinscherf, T. G., McEvoy, J. L., and Willis, D. K. 1998. A newly identified regulator is required for virulence and toxin production in Pseudomonas syringae. Mol. Microbiol. 28:917-929.

Koch, B., Nielsen, T. H., Sorensen, D., Andersen, J. B., Christophersen, C., Molin, S., Givskov, M., Sorensen, J., and Nybroe, O. 2002. Lipopeptide production in Pseudomonas sp. strain DSS73 is regulated by components of sugar beet seed exudate via the gac two-component regulatory system. Appl. Environ. Microbiol. 68:4509-4516.

Kokjohn, T. A., and Miller, R. V. 1985. Molecular cloning and characterization of the recA gene of Pseudomonas aeruginosa PAO. J. Bacteriol. 163:568-572.

Koopmann, B., Rollwage, H., Nollenburg, M., and Rudolph, K. 2001. Isolation and characterization of the algD gene of Pseudomonas syringae pv. phaseolicola and its distribution among other pseudomonads and related organisms. J. Phytopathol. 149:511-519.

Li, H. Q., and Ullrich, M. S. 2001. Characterization and mutational analy- 
sis of three allelic lsc genes encoding levansucrase in Pseudomonas syringae. J. Bacteriol. 183:3282-3292.

Li, L., Kang, D. G., and Cha, H. J. 2004. Functional display of foreign protein on surface of Escherichia coli using N-terminal domain of ice nucleation protein. Biotechnol. Bioeng. 85:214-221.

Li, X. Z., Starratt, A. N., and Cuppels, D. A. 1998. Identification of tomato leaf factors that activate toxin gene expression in Pseudomonas syringae pv. tomato DC3000. Phytopathology 88:1094-1100.

Lidell, M. C., and Hutcheson, S. W. 1994. Characterization of the hrpJ and hrpU operons of Pseudomonas syringae pv. syringae Pss61: similarity with components of enteric bacteria involved in flagellar biogenesis and demonstration of their role in harpin ${ }_{\text {Pss }}$ secretion. Mol. Plant-Microbe Interact. 7:488-497.

Lu, S. E., Scholz-Schroeder, B. K., and Gross, D. C. 2002. Characterization of the salA, syrF, and $s y r G$ regulatory genes located at the right border of the syringomycin gene cluster of Pseudomonas syringae pv. syringae. Mol. Plant-Microbe Interact. 15:43-53.

Lu, S. E., Soule, J. D., and Gross, D. C. 2003. Characterization of the $\operatorname{argA}$ gene required for arginine biosynthesis and syringomycin production by Pseudomonas syringae pv. syringae. Appl. Environ. Microbiol. 69:7273-7280.

Lu, S. E., Wang, N., Wang, J. L., Chen, Z. J., and Gross, D. C. 2005. Oligonucleotide microarray analysis of the salA regulon controlling phytotoxin production by Pseudomonas syringae pv. syringae. Mol. PlantMicrobe Interact. 18:324-333.

Mahé, B., Masclaux, C., Rauscher, L., Enard, C., and Expert, D. 1995. Differential expression of two siderophore-dependent iron-acquisition pathways in Erwinia chrysanthemi 3937: characterization of a novel ferrisiderophore permease of the ABC transporter family. Mol. Microbiol. 18:33-43.

Mazzola, M., and White, F. F. 1994. A mutation in the indole-3-acetic acid biosynthesis pathway of Pseudomonas syringae pv. syringae affects growth in Phaseolus vulgaris and syringomycin production. J. Bacteriol. 176:1374-1382.

McMorran, B. J., Merriman, M. E., Rombel, I. T., and Lamont, I. L. 1996 Characterization of the $p v d E$ gene which is required for pyoverdine synthesis in Pseudomonas aeruginosa. Gene 176:55-59.

Melchers, L. S., Regensburg-Tuink, A. J. G., Schilperoort, R. A., and Hooykaas, P. J. J. 1989. Specificity of signal molecules in the activation of Agrobacterium virulence gene expression. Mol. Microbiol. 3:969-977.

Mercier, J., and Lindow, S. E. 2000. Role of leaf surface sugars in colonization of plants by bacterial epiphytes. Appl. Environ. Microbiol. 66:369-374

Mo, Y. Y., Geibel, M., Bonsall, R. F., and Gross, D. C. 1995. Analysis of sweet cherry (Prunus avium L) leaves for plant signal molecules that activate the $s y r B$ gene required for synthesis of the phytotoxin, syringomycin, by Pseudomonas syringae pv. syringae. Plant Physiol. 107:603612

Mo, Y. Y., and Gross, D. C. 1991. Plant signal molecules activate the syrB gene, which is required for syringomycin production by Pseudomonas syringae pv. syringae. J. Bacteriol. 173:5784-5792.

Mossialos, D., Ochsner, U., Baysse, C., Chablain, P., Pirnay, J. P., Koedam, N., Budzikiewicz, H., Fernández, D. U., Schafer, M., Ravel, J., and Cornelis, P. 2002. Identification of new, conserved, non-ribosomal peptide synthetases from fluorescent pseudomonads involved in the biosynthesis of the siderophore pyoverdine. Mol. Microbiol. 45:1673-1685.

Narberhaus, F. 1999. Negative regulation of bacterial heat shock genes Mol. Microbiol. 31:1-8.

Nelson, K. E., Weinel, C., Paulsen, I. T., Dodson, R. J., Hilbert, H., dos Santos, V. A. P. M., Fouts, D. E., Gill, S. R., Pop, M., Holmes, M., Brinkac, L., Beanan, M., Deboy, R. T., Daugherty, S., Kolonay, J., Madupu, R., Nelson, W., White, O., Peterson, J., Khouri, H., Hance, I., Lee, P. C., Holtzapple, E., Scanlan, D., Tran, K., Moazzez, A., Utterback, T., Rizzo, M., Lee, K., Kosack, D., Moestl, D., Wedler, H., Lauber, J., Stjepandic, D., Hoheisel, J., Straetz, M., Heim, S., Kiewitz, C., Eisen, J., Timmis, K. N., Düsterhöft, A., Tümmler, B., and Fraser, C. M. 2002. Complete genome sequence and comparative analysis of the metabolically versatile Pseudomonas putida KT2440. Environ. Microbiol. 4:799-808.

Parkins, M. D., Ceri, H., and Storey, D. G. 2001. Pseudomonas aeruginosa GacA, a factor in multihost virulence, is also essential for biofilm formation. Mol. Microbiol. 40:1215-1226.

Peters, N. K., and Verma, D. P. S. 1990. Phenolic compounds as regulators of gene expression in plant-microbe interactions. Mol. Plant-Microbe Interact. 3:4-8.

Prentki, P., Karch, F., Iida, S., and Meyer, J. 1981. The plasmid cloning vector pBR325 contains a 482-base-pair-long inverted duplication. Gene 14:289-299.

Quigley, N. B., and Gross, D. C. 1994. Syringomycin production among strains of Pseudomonas syringae pv. syringae: conservation of the syrB and $s y r D$ genes and activation of phytotoxin production by plant signal molecules. Mol. Plant-Microbe Interact. 7:78-90.

Quigley, N. B., Mo, Y. Y., and Gross, D. C. 1993. SyrD is required for syringomycin production by Pseudomonas syringae pathovar syringae and is related to a family of ATP-binding secretion proteins. Mol. Microbiol. 9:787-801

Rahme, L. G., Mindrinos, M. N., and Panopoulos, N. J. 1992. Plant and environmental sensory signals control the expression of hrp genes in Pseudomonas syringae pv. phaseolicola. J. Bacteriol. 174:3499-3507.

Rhodes, D. R., Miller, J. C., Haab, B. B., and Furge, K. A. 2002. CIT: identification of differentially expressed clusters of genes from microarray data. Bioinformatics 18:205-206.

Rhodius, V. A., and LaRossa, R. A. 2003. Uses and pitfalls of microarrays for studying transcriptional regulation. Curr. Opin. Microbiol. 6:114-119.

Rich, J. J., Kinscherf, T. G., Kitten, T., and Willis, D. K. 1994. Genetic evidence that the gacA gene encodes the cognate response regulator for the lemA sensor in Pseudomonas syringae. J. Bacteriol. 176:74687475

Sawada, H., Suzuki, F., Matsuda, I., and Saitou, N. 1999. Phylogenetic analysis of Pseudomonas syringae pathovars suggests the horizontal gene transfer of $\arg K$ and the evolutionary stability of $h r p$, gene cluster. J. Mol. Evol. 49:627-644.

Sawahel, W., Sastry, G., Knight, C., and Cove, D. 1993. Development of an electrotransformation system for Escherichia coli DH10B. Biotechnol. Tech. 7:261-266

Scholz-Schroeder, B. K., Hutchison, M. L., Grgurina, I., and Gross, D. C. 2001a. The contribution of syringopeptin and syringomycin to virulence of Pseudomonas syringae pv. syringae strain B301D on the basis of sypA and syrBl biosynthesis mutant analysis. Mol. Plant-Microbe Interact. 14:336-348.

Scholz-Schroeder, B. K., Soule, J. D., Lu, S. E., Grgurina, I., and Gross, D. C. 2001b. A physical map of the syringomycin and syringopeptin gene clusters localized to an approximately 145-kb DNA region of Pseudomonas syringae pv. syringae strain B301D. Mol. Plant-Microbe Interact. 14:1426-1435.

Scholz-Schroeder, B. K., Soule, J. D., and Gross, D. C. 2003. The sypA, sypB and syp $C$ synthetase genes encode twenty-two modules involved in the nonribosomal peptide synthesis of syringopeptin by Pseudomonas syringae pv. syringae B301D. Mol. Plant-Microbe Interact. 16:271-280.

Shimoda, N., Toyoda-Yamamoto, A., Nagamine, J., Usami, S., Katayama, M., Sakagami, Y., and Machida, Y. 1990. Control of expression of Agrobacterium vir genes by synergistic actions of phenolic signal molecules and monosaccharides. Proc. Natl. Acad. Sci. U.S.A. 87:6684-6688.

Stachel, S. E., Messens, E., Van Montagu, M., and Zambryski, P. 1985. Identification of the signal molecules produced by wounded plant cells that activate T-DNA transfer in Agrobacterium tumefaciens. Nature 318:624-629

Staskawicz, B., Dahlbeck, D., Keen, N., and Napoli, C. 1987. Molecular characterization of cloned avirulence genes from race- 0 and race- 1 of Pseudomonas syringae pv. glycinea. J. Bacteriol. 169:5789-5794.

Sundin, G. W., and Murillo, J. 1999. Functional analysis of the Pseudomonas syringae rulAB determinant in tolerance to ultraviolet B (290-320 $\mathrm{nm})$ radiation and distribution of rulAB among $P$. syringae pathovars. Environ. Microbiol. 1:75-87.

Tanaka, K., and Takahashi, H. 1991. Cloning and analysis of the gene (rpoDA) for the principal sigma factor of Pseudomonas aeruginosa. Biochim. Biophys. Acta 1089:113-119.

Vidaver, A. K. 1967. Synthetic and complex media for rapid detection of fluorescence of phytopathogenic pseudomonads: effect of carbon source. Appl. Microbiol. 15:1523-1524.

Wang, N., Lu, S.-E., Yang, Q., Sze, S.-H., and Gross, D. C. 2006. Identification of the syr-syp box in the promoter regions of genes dedicated to syringomycin and syringopeptin production by Pseudomonas syringae pv. syringae B301D. J. Bacteriol. 188:160-168.

Wei, Z. M., Sneath, B. J., and Beer, S. V. 1992. Expression of Erwinia amylovora hrp genes in response to environmental stimuli. J. Bacteriol. 174:1875-1882.

West, S. E. H., Schweizer, H. P., Dall, C., Sample, A. K., and Runyenjanecky, L. J. 1994. Construction of improved EscherichiaPseudomonas shuttle vectors derived from pUC18/19 and sequence of the region required for their replication in Pseudomonas aeruginosa. Gene 148:81-86

Willis, D. K., Hrabak, E. M., Rich, J. J., Barta, T. M., Lindow, S. E., and Panopoulos, N. J. 1990. Isolation and characterization of a Pseudomonas syringae pv. syringae mutant deficient in lesion formation on bean Mol. Plant-Microbe Interact. 3:149-156.

Xiao, Y. X., Lu, Y., Heu, S. G., and Hutcheson, S. W. 1992. Organization and environmental regulation of the Pseudomonas syringae pv. syrin- 
gae 61 hrp cluster. J. Bacteriol. 174:1734-1741.

Xiao, Y. X., and Hutcheson, S. W. 1994. A single promoter sequence recognized by a newly identified alternate sigma factor directs expression of pathogenicity and host range determinants in Pseudomonas syringae. J. Bacteriol. 176:3089-3091.

Yura, T., and Nakahigashi, K. 1999. Regulation of the heat-shock response. Curr. Opin. Microbiol. 2:153-158.

Zhang, J. H., Quigley, N. B., and Gross, D. C. 1995. Analysis of the syrB and $\operatorname{syr} C$ genes of Pseudomonas syringae pv. syringae indicates that syringomycin is synthesized by a thiotemplate mechanism. J. Bacteriol. 177:4009-4020

Zhang, J. H., Quigley, N. B., and Gross, D. C. 1997. Analysis of the syrP gene, which regulates syringomycin synthesis by Pseudomonas syringae pv. syringae. Appl. Environ. Microbiol. 63:2771-2778.
Zhang, S., and Sundin, G. W. 2004. Mutagenic DNA repair potential in Pseudomonas spp., and characterization of the rulABPc operon from the highly mutable strain Pseudomonas cichorii 302959. Can. J. Microbiol. 50:29-39.

\section{AUTHOR-RECOMMENDED INTERNET RESOURCE}

Bioalma SOTA website: www.almabioinfo.com/sota Department of Energy Joint Genome Institute (JGI): www.jgi.doe.gov/JGI_microbial

JGI Eukaryotic Genome website: genome.jgi-psf.org/

JGI Integrated Microbial Genomes webpage: /img.jgi.doe.gov/cgibin/pub/main.cgi 